Review

\title{
A Short Review about the Partial Methane Oxidation in Fuel Cell-Type Reactors for Co-Generation of Energy and Chemicals
}

\author{
Rodrigo F.B. de Souza ${ }^{a}$ Daniel Z. Floriob ${ }^{b}$ Ermete Antolinic and Almir O. Neto ${ }^{a}$ \\ a Centro de Celulas a Combustivel e Hidrogenio, Instituto de Pesquisas Energeticas e Nucleares, Av. Prof. \\ Lineu Prestes, 2242 Cidade Universitária, CEP 05508-900, São Paulo, SP, Brazil \\ b Centro de Engenharia, Modelagem e Ciências Sociais Aplicadas \\ Universidade Federal do ABC, Av. dos Estados, 5001, Santa Terezinha, Santo André CEP 09210-580, SP, \\ Brazil \\ c Scuola di Scienzadei Materiali, Via 25 Aprile 22, 16016 Cogoleto, Genova, Italy \\ correponses:E-mail: aolivei@usp.br
}

\begin{abstract}
The conversion of methane into chemicals is of interest to achieve a decarbonized future. Fuel cells are electrochemical devices commonly used to obtain electrical energy, but can be utilized either for chemicals production or both energy and chemicals cogeneration. In this work, the partial oxidation of methane in fuel cells for electricity generation and valuable chemicals production at the same time is reviewed. For this purpose, different types of methane-fed fuel cells, both low temperature fuel cells, such as PEMFCs and AAEMFCs, and high temperature fuel cells, such as SOFCs. Despite the fact that few studies have been conducted on this subject, the promising results are driving the development of fuel cells that use methane as a fuel source for the cogeneration of power and valuable chemicals.
\end{abstract}

Keywords: fuel cell; methane to energy; methane to products; methane oxidation reaction

\section{INTRODUCTION}

Methane is the second most abundant greenhouse gas behind $\mathrm{CO}_{2}$, but is more potent in trapping heat, having a detrimental impact in the atmosphere [1]. On the other hand, this gas is the major component of natural gas, and has lower overall costs, which par excellence makes it a primary source for energy. There are large reserves of this gas, being the main fraction of natural gas, coal bed gas, shale gas, and biogas, and it is also associated with oil extraction, where it is usually burned when in remote fields [2, 3].

In a world that is geared towards reducing the carbon footprint, methane is identified as a possible source of transition energy, due to its low extraction and logistics costs, which can discourage the use of other fossil fuels [4,5]. However, even though the energy efficiency of burning liquefied methane is comparable to that of other liquid fuels, it is still used mainly for burning, generating $\mathrm{CO}_{2}$ [4]. For this reason, the conversion of methane into chemicals is of interest to achieve a decarbonized future [2]. Direct conversion of methane, however, presents some challenges, such as the breaking of the $\mathrm{C}-\mathrm{H}$ bond, stronger than in any other hydrocarbon $\left(434 \mathrm{~kJ} \cdot \mathrm{mol}^{-1}\right)$, and the low polarizability, due to its regular tetrahedron conformation [6-11].

Methanol is an important industrial chemical, widely used in chemical synthesis, for the manufacture of many other chemicals [12-14]. It is also used in automotive antifreezes, in rocket fuels, and as a general solvent. Methanol is also a high-octane, clean-burning fuel that is a potentially important substitute for gasoline in automotive vehicles. Methanol is an alcohol present in nature in small amounts and, obtained anthropologically by pyrolysis or destructive distillation of wood. Demand for methanol is expected to exceed 110 million tons per year (MTY) in the next years and is expected to increase the production capacity [15]. Methanol is commonly obtained from fossil fuels, but it can also be obtained from renewable energy resources, supporting in this way the development of energy 
solutions with reduced greenhouse gas emissions. Besides their high-energy content, fossil fuels are hydrocarbon mixtures, that provide low-cost feedstock for the production of various platform chemicals [16], from fossil fuels, there is methane gas.

In most cases, the conversion process from methane to methanol is not completely selective, and, among different compounds, it is possible to find mainly formate. Other compounds with a higher carbon chain, such as ethane, ethanol, and propane, are also found, but less frequently and under more specific experimental conditions [17, 18].

A classical process for conversion of methane into products involves the hydrocarbon and water decomposition to $\mathrm{CO}+\mathrm{H}_{2}$ (syngas) at high temperatures and pressures, an extremely energy intensive process due to chemical inertness of the $\mathrm{C}-\mathrm{H}$ bond. As such, the development of more efficient processes is an active field and a variety of ways has been explored [19-21]. Among others ways, these include homogenous and heterogeneous catalysis, photocatalysis, biocatalysis, plasma technologies, and electrochemical processes $[2,6,22-28]$.

All these processes can be conducted in mild conditions, such as the homogeneous catalytic process that consists of partial oxidation of methane by means of strong oxidizing species, $\mathrm{H}_{2} \mathrm{SO}_{4}[28,29]$ in oleum and $\mathrm{H}_{2} \mathrm{O}_{2}[6,27,30-32]$, enhanced by metal ions, generating reactive oxygenated species.

In the bioconversion of methane in bacterial cells, Methane Monooxygenase (MMO) oxidizes methane to methanol using molecular oxygen and electron donors at room temperature and pressure $[26,33,34]$. This enzyme is biosynthesized by methane-oxidizing bacteria, which are microorganisms that utilize methane as a carbon and energy source [14]. The ability of MMO to cleave the $\mathrm{C}-\mathrm{H}$ bond of methane under mild conditions is believed to originate from the generation of extremely reactive oxygen species at the catalytic site of MMO. Thus, the structure and properties of the catalytic site in MMO and the reactive oxygenated species involved in the catalysis have been investigated.

The photocatalytic process takes place by the ability of the catalyst to create electronhole pairs, which generate free radicals [35-37], or reactive oxygenated species [6, 38]. This process can be associated to hydrogen peroxide decomposition, enhancing the conversion $[35,38]$. Shi and co-workers [38] synthesized and investigated a fluffy mesoporous graphitic carbon nitride ( $\mathrm{g}-\mathrm{CN})$, for the partial oxidation of methane to methanol at a mild condition $\left(35^{\circ} \mathrm{C}\right)$ in the presence of $\mathrm{H}_{2} \mathrm{O}_{2}$ under the irradiation of simulated sunlight.

$\mathrm{Li}$ and co-workers [39] applied a selective photocatalytic oxidation over graphitic carbon nitride-decorated tungsten bronze cesium nanocomposites to the conversion of low concentration methane under mild conditions into methanol under light irradiation and at room temperature. The superoxide anion radical $\left(\bullet \mathrm{O}_{2}-\right)$ first activated the methane and then the photogenerated electrons from nanocomposites in the composite inhibited the peroxidation and increased the generation of methanol [36, 39].

Finally, electrochemical processes play an important role, as they act directly on the electrostatic interactions between electron and atomic nucleus through the direct potential application on an atom or molecule, reducing energy dispersion in the environment [40]. This review presents a perspective of the oxidation of methane by electrochemical ways to obtain products with higher added value, preferably with co-generation of electricity. Discussing how the application of fuel cells as reactors, the methane is consumed, its released electrons are used for electrical work, and products such as methanol are obtained. In a major plan, the potential of the application of crude natural gas $\left(\mathrm{CH}_{4}+\mathrm{CO}_{2}\right)$ and we discussed some of the most promising materials to be explored.

\section{ELECTROCHEMICAL METHODS FOR METHANE OXIDATION}

Electrochemical processes can be carried out at both high and low temperatures, and present the advantage of transfer the energy directly from the hydrocarbon to the system, reducing the dissipation of energy in the form of thermal energy [40-44]. In addition, there are the possibility to select specific reaction products with the adjustment of work 
potential. For example, Ramos et al [18] investigated methane oxidation over $\mathrm{Pd} / \mathrm{C}$ using a polymer electrolyte reactor - fuel cell type at mild condition, to obtain methanol, formic acid, formaldehyde, ethane, ethanol, acetaldehyde, acetic acid and propane, reporting the onset potential for each product.

The electrochemical oxidation of methane can occur in two ways, that is, the direct way, in which the hydrocarbon electron is transferred directly to the electrical system, and the indirect way, involving the electrogeneration of highly reactive species capable of reacting with $\mathrm{CH}_{4}$ in the interface neighborhoods or/and in the bulk of the solution [45]

\subsection{Faradaic Methane Oxidation}

Faradaic methane oxidation is based on the adsorption of methane on the catalyst active site and on the direct electron exchange between the hydrocarbon and the electrode surface. Sustersic et al [46] reported the adsorption of methane and its oxidation at various potentials on platinum in $\mathrm{H}_{2} \mathrm{SO}_{4}$ solution at $60^{\circ} \mathrm{C}$. The existence of two electrosorbed species, $\mathrm{COH}$-type and $\mathrm{CO}$-type, was highlighted through the current/potential characteristics recorded under different perturbation conditions.

Nandenha et al. [47] studied the Pt/C, Pt/C-ATO, Pd/C and Pd/C-ATO catalysts for methane oxidation: cyclic voltammograms of all electrocatalysts after adsorption of methane showed a current increase during the anodic scan, more pronounced for materials supported in C-ATO, related to the adsorption of methane and oxidation of the adsorbed species through the water activation. For all electrocatalysts, adsorbed CO or HCO intermediate species were observed by in-situ Atenued Total Reflectance - Fourier Transformed Infrared (ATR-FTIR) experiments.

Boyd and co-workers[48] investigated the electrochemical conversion of methane to $\mathrm{CO}_{2}$ on platinum under ambient conditions. Theoretical calculations suggested that methane is thermochemically activated on Pt surfaces $\left(\mathrm{CH}_{4(\mathrm{~g})} \rightarrow \mathrm{CH}_{3}{ }^{*}+\mathrm{H}^{*}\right)$ and that the stable methane-derived surface intermediate was $\mathrm{CO}^{*}$. They observed that catalysts with strong $\mathrm{CO}^{*}$ binding and weak $\mathrm{OH}^{*}$ binding energy are the most effective for high methane oxidation efficiency, but only at high potentials. These results are in line with those reported by Hahn et al. [49], which through FTIR studies, showed the existence of oxygenated carbonaceous species at potentials greater than $0.55 \mathrm{~V}$ over $\mathrm{Pt}, \mathrm{Au}, \mathrm{Pd}, \mathrm{Rh}$ and $\mathrm{Ru}$. Arnarson and co-worker [50] identify a surface catalytic limitation of methane oxidation to methanol in terms of a compromise between selectivity and activity, as oxygen evolution is a competing reaction. By investigating two classes of materials, rutile oxides and two-dimensional transition metal nitrides and carbides, they found a linear relationship between the energy needed to activate methane, that is, to break the first $\mathrm{C}-\mathrm{H}$ bond, and oxygen binding energies on the surface. Based on a simple kinetic model they concluded that to obtain sufficient activity oxygen has to bind weakly to the surface, but there is an upper limit to retaining selectivity.

Various authors, working on faradaic reactions, reported the importance of water activation, as one of the ways to transfer oxygen to the hydrocarbon molecule to obtain methanol [48, 50]. Rocha [42] studied the methane oxidation in a bath reactor with $\mathrm{TiO}_{2} / \mathrm{RuO}_{2} / \mathrm{V}_{2} \mathrm{O}_{5}$ gas diffusion electrode and observed that the reaction occurs by a traditional mechanism in which the discharge of water generates hydroxyl radicals, which, in turn, chemically adsorb onto the oxide surface. This is in agreement with previous reports in the literature $[9,51]$, however these radicals can not only react with adsorbed species, but also detach themselves from the bulk and react without electron transfer to the electrode. A scheme of the electrochemical reactor described by Rocha et al. [42] is shown in Fig. 1. 


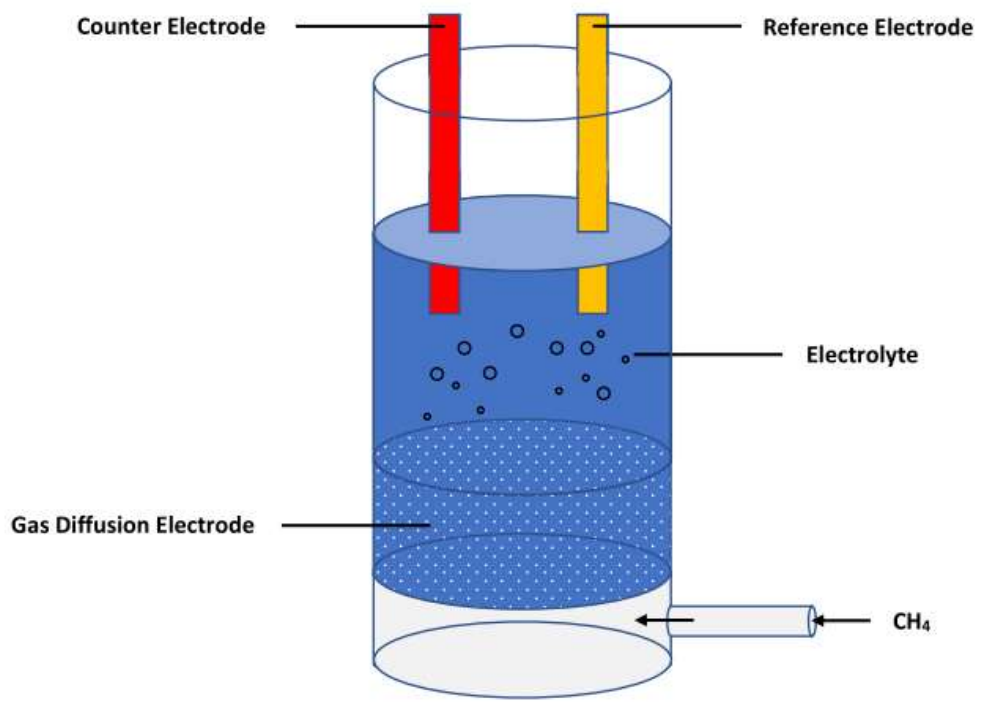

Figure 1. scheme of the electrochemical reactor described by Rocha et al. [42].

\subsection{Non-Faradaic Methane Oxidation}

Methane can be activated by more reactive species originated by faradaic processes, that is, reactive oxygenated species (ROS), such as $\mathrm{OH} \bullet[18,52,53], \mathrm{O}_{2} \bullet[54]$ and $\mathrm{SO}_{3}[55$, $56]$, these species being capable to activating the $\mathrm{C}-\mathrm{H}$ bond, without the need to absorb methane on the electrode.

Cui et al. [57] in a recent review reported that the dissociation of $\mathrm{H}_{2} \mathrm{O}_{2}$ can generate $\mathrm{OH} \bullet$ and these radicals produce $\mathrm{C}_{1}$ compounds and $\mathrm{CH}_{3} \bullet$ radicals. The $\mathrm{CH}_{3} \bullet$ radicals can activate water and other hydrocarbon molecules. Cook et al. [52] reported a cathodic reaction to electrogenerate $\mathrm{H}_{2} \mathrm{O}_{2}$, then this specie is activated by Fenton reaction to $\mathrm{OH} \bullet$ and finally this radical converts the methane into methanol. Neto's group $[18,53,58]$ attributed the oxidation of methane at lower overpotential in other products, with co-generation of energy, to the activation of water and the presence of $\mathrm{OH} \bullet$ radicals, arising from water activation.

Although ROS are the most commonly applied species for the partial oxidation of methane, other radicals can also be used. The use of a photo-electrochemical system to generate a chlorine radical, that reacts with methane to produce methanol was reported by Ogura [59]. $\mathrm{Cl}^{-}$is produced by an electrochemical reaction, and then this ion is turned into a radical under $\mathrm{UV}$ light. $\mathrm{Cl} \bullet$ reacts with $\mathrm{CH}_{4}$ generating methyl chloride, whose subsequent hydrolysis produces methanol.

Studies demonstrated that the methane-oxygen cyclic operation was not necessary to obtain high selectivity $[60,61]$. The active oxygen species responsible for the catalytic conversion of methane into oxygenated products has to be clarified because the reaction could proceed either in the gas phase through a chain propagation mechanism [62-64] and/or on the catalyst surface [58, 65-67].

Frese et al.[54] using an electrochemical cell to convert $\mathrm{O}_{2}$ into $\mathrm{O}_{2} \bullet-$ to obtain formaldehyde from methane, reported that there is a correlation between the current density and the selectivity, that is, increasing the current density increases the amount of ROS produced, and these species promote the production of more oxidized chemicals, such as $\mathrm{CO}$ and $\mathrm{CO}_{2}$.

The propagation stage of radical reaction at mild conditions can promote the formation of non-oxygenated radicals, such as the methyl radical $\left(\mathrm{CH}_{3} \bullet\right)$, and the detection of C2 and C3 compounds such as ethane and propane by Ramos et al. [18] is evidence of the formation of the methyl radical, these pathways was represented in scheme 1 .

Methyl radical formation occurs by $\mathrm{H}$ abstraction from $\mathrm{CH}_{4}$ by hydroxyl radicals. Gaseous methane first binds to the metallic sites [61], then hydrogen atoms are gradually 
abstracted by the adjacent surface $\mathrm{M}-\mathrm{O}$ sites and yield $\mathrm{M}-\mathrm{OH}$. The reverse reaction of hydroxyl recombination is favored by $\mathrm{H}_{2} \mathrm{O}[6,37,61,64,68,69]$.

Methane activation chemistry and oxidative coupling of methane remain to date a subject of interest related to the initial methyl radical formation site and the role of surfaceinitiated gas-phase radical reactions [64, 70-73].

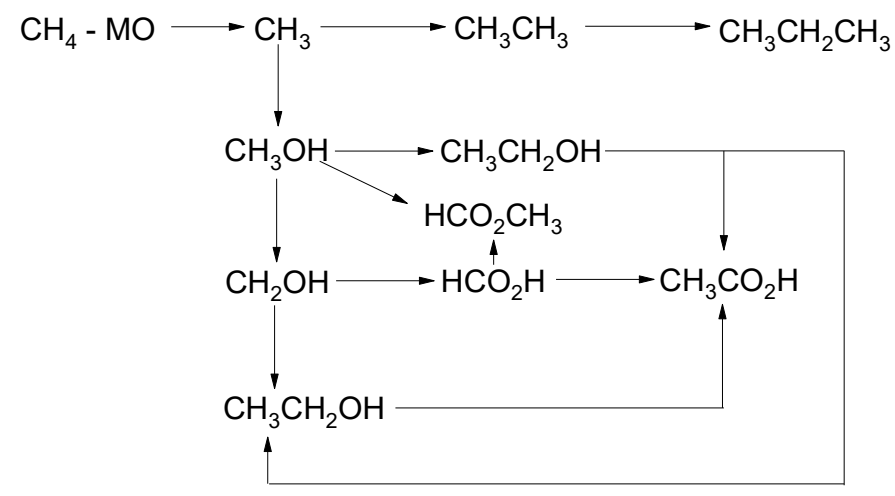

Scheme 1. methane partial oxidation pathway proposed by Ramos et al. [18].

\section{FUEL CELLS}

Fuel cells are a tool commonly used to convert chemical energy into electrical energy, and are also used as a reactor for chemical transformations. Therefore, they can generate only energy (classic use), only valuable chemicals or both energy and valuable chemicals. While a previous review on methane-fed fuel cells was addressed to the production of only chemicals [10], this review deals with both energy and chemicals generation.

Vayenas et al. [74] compared the suitability of a cogeneration solid oxide fuel cells (SOFC) with respect to a chemical reactor of the same capacity giving the same product composition. Their model showed that such a relative suitability depends on the value of the dimensionless number, $v$, defined as:

$$
v=[24 \alpha(K \mathrm{E}-K \mathrm{H}) t \mathrm{C} / \alpha C \mathrm{C}-C \mathrm{R}]
$$

where $K E$ is the unit electrical energy price (in $\$ \mathrm{kWh}^{-1}$ ), $\mathrm{KH}$ the price per thermal unit produced in $\left(\$ \mathrm{kWh}^{-1}\right), t \mathrm{C}$ the cogenerative SOFC useful lifetime (in days), CC the co-generative fuel cell capital investment per unit installed power (in $\$ \mathrm{~kW}^{-1}$ ), $C R$ the chemical reactor capital investment per unit installed capacity (in $\$$ day $\mathrm{kW}^{-1}$ ) and $\alpha$ is a conversion factor given in the economical model. On these bases, a cogeneration fuel cell is more advantageous than a chemical reactor if $v>1$.

At the beginning of the second half of the twentieth century, the use of hydrocarbons as fuel for fuel cells was considered, and the adsorption and oxidation characteristics of hydrocarbons were investigated [75-78]: it was reported that hydrocarbons adsorb slowly while undergoing dissociation on platinum electrodes in a narrow potential range around the final cathodic part of the double layer region and can be oxidized in an anodic potential sweep. Since the 1960s, with the observation that methane oxidation occurred only at high overpotentials, studies for non-protic electrolytes led to ceramic systems and subsequently to the use of hydrocarbon as fuel for SOFCs [79]. In the 21st century, with the improvement of proton exchange fuel cell (PEMFCs), $\mathrm{CH}_{4}$ started to be considered as fuel under mild conditions.

The performance of a methane-fueled proton exchange fuel cell was reported by Tyagi et al.[80], applying a Nafion membrane doped with phosphoric acid, obtaining an open circuit value of $\sim 0.55 \mathrm{~V}$ using Pt catalysts. Nandenha et al. [47] using Pd/C as the anode catalyst obtained a power density of $0.5 \mathrm{~mW} \mathrm{~cm}^{-2}$ in a PEMFC fueled by methane at $80^{\circ} \mathrm{C}$. In a later work, Nandenha et al. [81] obtained a power density of $c a .0 .6 \mathrm{~mW} \mathrm{\textrm {cm } ^ { - 2 }}$ due to the effect of $\mathrm{Zn}$ addition to $\mathrm{Pd}$, that enhances the water activation and the 
production of methanol and formate, which are more easily converted into energy than methane itself. Among different Pd-based catalysts, a power density of $c a .1 \mathrm{~mW} \mathrm{~cm}^{-2}$ was obtained using PdAu as the anode catalyst, due to the methane interaction with the noble metals in the region of hydrogen adsorption; the formation of methanol and formate at water activation potentials was observed [82].

\section{FUEL CELLS FOR COGENERATION OF ENERGY AND CHEMICALS}

The fuel cells can be applied to methane oxidation for obtain energy, added value products, and both, and in all cases the differential is the material and operation conditions. As can be seen in Fig. 2, methane oxidation can occur both at the anode or cathode side. Otsuka and Yamanaka [83] reported the partial oxidation of alkenes at low temperatures $\left(<100{ }^{\circ} \mathrm{C}\right)$ using gaseous alkene- $\mathrm{O}_{2}$ fuel cell systems and for hydroxylation of alkanes and aromatics applying $\mathrm{H}_{2}-\mathrm{O}_{2}$ fuel cell reactions, which control the reaction rate and selectivity by a variable resister or potentiostat in the outer circuit. On this basis, Hibino's group $[9,84]$ used a fuel cell as an electrolytic reactor to convert methane into methanol at different temperatures $\left(50-250{ }^{\circ} \mathrm{C}\right)$, and attributed the high conversion to the production of $\mathrm{O}_{2}{ }^{*}$ - obtained from the activation of water over vanadium and tin oxides.

Spinner and Mustain [85], used a $\mathrm{CO}_{3}{ }^{2-}$ exchange polymer in a fuel cell type reactor, to convert methane to $\mathrm{CH}_{3} \mathrm{OH}, \mathrm{HCHO}, \mathrm{CO}, \mathrm{HCOO}$ and other low molecular weight oxygenate species at room temperature. The methane was activated electrochemically on a $\mathrm{NiO}-\mathrm{ZrO}_{2}$ electrocatalyst and the carbonate anions were used as an oxygen donor to facilitate methane activation.

Nandenha and co-workers [86], generated methanol through partial oxidation of methane at the cathode of a solid membrane reactor-PEMFC type $\left(\mathrm{H}_{2} / \mathrm{H}_{2} \mathrm{O}_{2}+\mathrm{CH}_{4}\right)$ at room temperature. $\mathrm{CH}_{4}$ was injected into the cathode together with a $\mathrm{H}_{2} \mathrm{O}_{2}$ solution. They observed that the catalytic layer adsorbed methane and $\mathrm{H}_{2} \mathrm{O}_{2}$ in the active sites, generating $\mathrm{OH} \bullet$ radicals, that reacted with the methane, giving rise to methanol formation. Methanol production was higher at the potential range of $600-400 \mathrm{mV}$.

a)

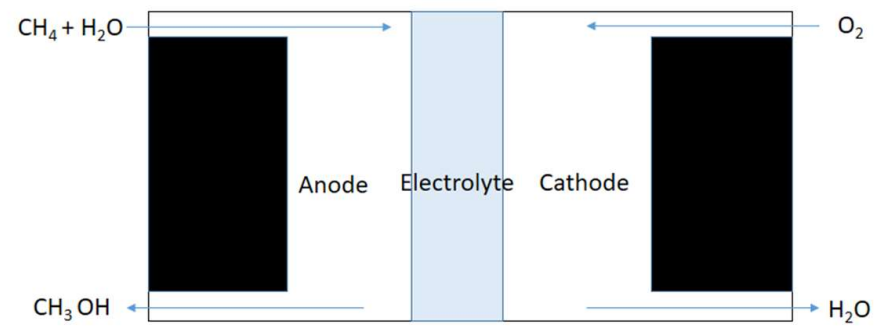

b)

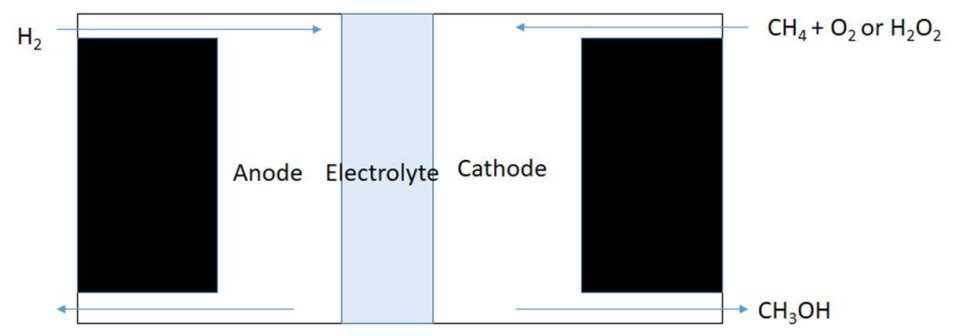




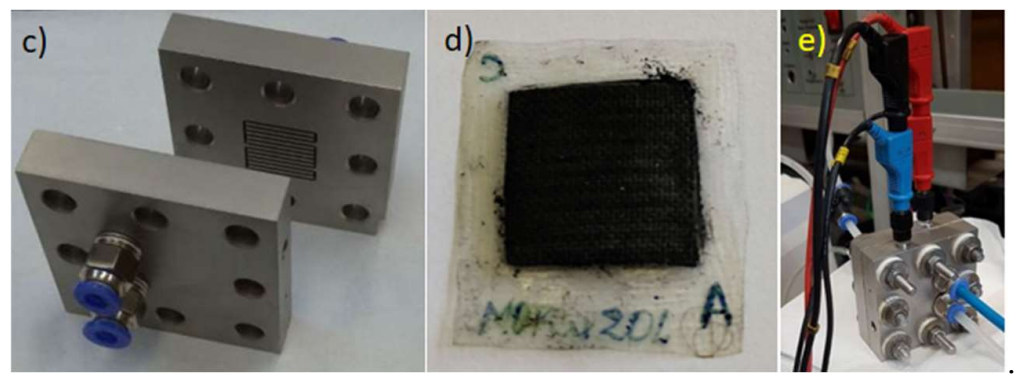

Figure 2. Fuel Cell Basic architecture: oxidation of methane a) at the anode side and b) at the cathode side. c) reactor plates, d) Membrane- electrode assemble, e) reactor type fuel cell.

Santos et al [58] carried out the partial oxidation of methane for cogeneration of power and chemicals on $\mathrm{Pt} / \mathrm{C}, \mathrm{Pd} / \mathrm{C}$ and $\mathrm{Ni} / \mathrm{C}$ in an alkaline anion exchange membrane fuel cell (AAEMFC). FTIR data suggests that methane was converted into small organic molecules such as methanol and formate at different potentials for $\mathrm{Pt} / \mathrm{C}, \mathrm{Pd} / \mathrm{C}$, and $\mathrm{Ni} / \mathrm{C}$. The highest conversion efficiency was about $20 \%$ at $0.3 \mathrm{~V}$ using a Pt/C catalyst, the maximum conversion over $\mathrm{Pd} / \mathrm{C}$ was $17.5 \%$ at $0.15 \mathrm{~V}$, associated with the formation of a thin layer of $\mathrm{PdO}$ on the catalytic surface.

In later work, Neto's Group [87] investigated the effect of $\mathrm{Ni}$ content in $\mathrm{PdNi} / \mathrm{C}$ catalysts used as anode materials in AAEMFCs on the fuel cell performance and methanol selectivity. They observed that the increase Ni content enhances the energy generation and the formation of products more oxidized than methanol, probably due to the high ability of $\mathrm{NiO}_{x}$ to activate water monitored by electrochemical experiments with Raman spectroscopy in situ using a electrochemical cell shown in figure 3.

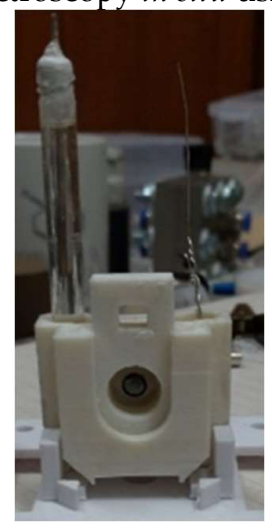

Figure 3. electrochemical cell for Raman spectroscopy in situ, described in Santos [87].

For partial oxidation of methane by the electrochemical method, water activation is necessary $[48,50]$, in which the hydroxyl radicals can be produced directly by the oxidation of water (equation 2) [88].

$$
\mathrm{M}+\mathrm{H}_{2} \mathrm{O} \rightarrow \mathrm{M}(\mathrm{OH} \bullet)+\mathrm{H}^{+}+\mathrm{e}^{-}
$$

This radical can be detected indirectly by the formation of hydrogen peroxide generated by the chemical equilibrium of this radical, according to equation (3) [89]:

\section{$2 \mathrm{OH} \bullet \mathrm{M} \rightarrow \mathrm{H}_{2} \mathrm{O}_{2}$ or $\mathrm{HO}_{2}{ }^{-1}$ in alkaline medium}

The detection of $\mathrm{H}_{2} \mathrm{O}_{2}$ electrochemically is carried out by rotation ring disk electrode (RRDE) experiments. Garcia et al [53] used RRDE to give an indication of the most suitable percentage of $\mathrm{Cu}$-complex, that should be used for the conversion of methane to methanol in alkaline medium. Godoi and co-workers [90] used this methodology to evaluate $\mathrm{Pd}_{x-}$ $\mathrm{Cu}_{\mathrm{y}} / \mathrm{C}$ electrocatalysts for methanol production from methane partial oxidation, and observed that the most active materials showed a content of $\mathrm{H}_{2} \mathrm{O}_{2}$ of about $\sim 5-6 \%$, 
similar to that reported by Garcia [53]; materials generating a $\mathrm{H}_{2} \mathrm{O}$ content higher than $6 \%$, however, presented lower methanol production. For high $\mathrm{H}_{2} \mathrm{O}_{2}$ content, carbonate was detected in the products, inferring that the excess of ROS can lead to more oxidized products. The dependence on water activation alters the rate of reaction for methanol formation as shown in figure 4

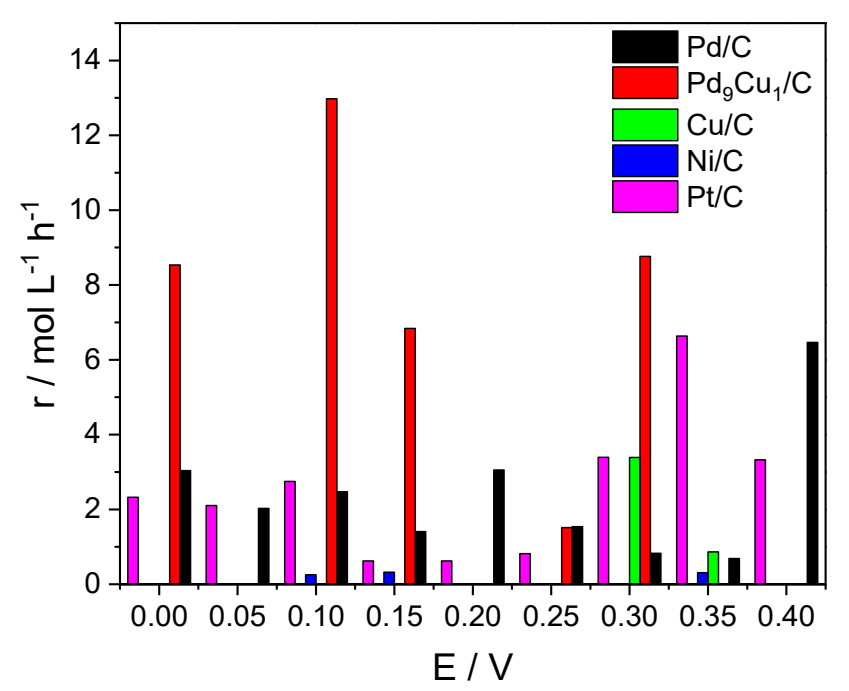

Figure 4. Rate reaction for methanol production in potential function of transition metals electrocatalyst, Data extracted by $[58,87,91]$.

\section{HIGH TEMPERATURE FUEL CELLS}

Solid oxide fuel cells (SOFCs), operating at high temperatures, thus minimizing polarization losses and of the effect of impurities, are good candidate for the cogeneration of electricity and chemicals. Kiratzis et [92] used a SOFC for the chemical cogeneration of hydrogen cyanide, used in the synthesis of adiponitrile, in fumigation, as insecticide, in electroplating, metallurgy and photography. This cell is formed by a tube of YSZ enclosed in a quartz tube, containing a porous Pt electrode as the cathode and a porous rhodium and platinum electrode as the anode, operating in the range $800-1000{ }^{\circ} \mathrm{C}$, and using a mixture of methane and ammonia as the fuel, as the following anodic reaction:

$$
\mathrm{CH}_{4(\mathrm{~g})}+\mathrm{NH}_{3(\mathrm{~g})}+3 \mathrm{O}^{2-} \rightarrow \mathrm{HCN}_{(\mathrm{g})}+3 \mathrm{H}_{2} \mathrm{O}_{(\mathrm{g})}+6 \mathrm{e}^{-}(4)
$$

HCN selectivity depends on the fuel composition, temperature and current density. The cell selectivity to HCN could exceed $75 \%$. The addition of oxygen to the fuel positively affects the cell selectivity to HCN. For the currents tested, the only by-products formed were $\mathrm{CO}$ and $\mathrm{N}_{2}$ and a power density of $\mathrm{ca} .0 .01 \mathrm{Wcm}^{-2}$ was generated. Selective oxidation of methane in SOFC was studied for co-generation of C2 hydrocarbons and synthesis gas.

Oxidative coupling reactions of methane, such as the synthesis of ethylene and ethane, aroused a lot of interest. Oxidation coupling of methane using a SOFC is an effective way to obtain $\mathrm{C} 2$ compounds and to generate energy at the same time [79, 93-95]. The use of SOFC reactor for co-generation of $\mathrm{C}_{2}$ hydrocarbons and electrical power was first reported by Pujareand Sammells [93], in which a high selectivity to $C_{2}$ hydrocarbons (>90\%) was achieved but with low conversion.

Otsuka et al. [94] used a SOFC with yttria-stabilized zirconia (YSZ) as a solid electrolyte for the oxidative coupling of methane. Among various catalysts, the most active and selective was $\mathrm{BaCO}_{3}(86 \%$ C2 selectivity) deposited on $\mathrm{Au}$ anode. The effects of temperature on the rates of products and C2 selectivity was investigated: the formation rate of C2 compounds and C2 selectivity showed maxima at $1073 \mathrm{~K}$. The higher the pressure of methane, the better for the cogeneration of C2 hydrocarbons and electricity. An increase in 
the pressure of oxygen at the cathode also enhanced the rate of $\mathrm{C} 2$ formation and current, but the $\mathrm{C} 2$ selectivity did not change appreciably.

However, the conversion of methane and $\mathrm{C} 2$ yield are still very low $(<2 \%)$. Guo et al. [95] utilized a SOFC with $1 \mathrm{wt} \% \mathrm{Sr} / \mathrm{La}_{2} \mathrm{O}_{3}-\mathrm{Bi}_{2} \mathrm{O}_{3}-\mathrm{Ag}-\mathrm{YSZ}$ membrane for the oxidative coupling of methane. An increase in the current generated was accompanied by a decrease in C2 selectivity and an increase in methane conversion. Methane conversion decreased, $\mathrm{C} 2$-selectivity increased and current generated decreased slightly with a rise in total flow rates. $\mathrm{CH}_{4}$ conversion and the current generated increased with a rise in oxygen concentration. High methane concentrations are the more suitable conditions for the cogeneration of electrical energy and ethane and ethylene.

Tagawa et al. [79] used a SOFC for a selective oxidation reactor and for the conversion

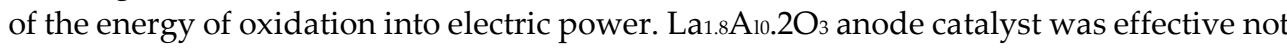
only to prevent the total oxidation of methane, but also to prevent carbon deposition. A thin thickness YSZ composite was used as the electrolyte in the SOFC reactor. A temperature higher than $1200 \mathrm{~K}$ the yield of valuable chemicals $\left(\mathrm{CO}\right.$ and $\left.\mathrm{C}_{2}\right)$ were much higher than that of $\mathrm{CO}_{2}$. The selectivity of $\mathrm{CO}_{2}$ was always below $20 \%$. Thus, this reactor can be regarded as a high selective oxidation reactor. The free energy change of the oxidation reaction has been directly converted into electric power with high efficiency.

The production of $\mathrm{C} 2$ hydrocarbons and electricity from oxidative coupling of methane in an SOFC reactor was simulated [96]. $\mathrm{La} 0.85 \mathrm{Sr} 0.15 \mathrm{MnO}_{3 / 8} \mathrm{~mol} \% \mathrm{Y}_{2} \mathrm{O}_{3}-\mathrm{ZrO}_{2} / \mathrm{La}_{1.8} \mathrm{~A}_{10.82} \mathrm{O}_{3}$ (LSM/YSZ/LaAlO) were used as a cathode, electrolyte and an anode, respectively. A plug flow reactor model (PFRM) was developed using kinetic parameters of the oxidative coupling of methane and the oxygen permeability through LSM/YSZ/LaAlO from the previous work [79]. Good agreements of power generation between experimental and simulation results were obtained. The effect of operating conditions was investigated. Methane conversion and $\mathrm{C} 2$ selectivity increase with increasing operating temperature. In this system, most of $\mathrm{C} 2$ production is ethylene, which is more favored than ethane. Methane conversion decreases with increasing methane feed flow rate while C2 selectivity slightly increases. Higher methane feed concentrations on the anode give higher power. The reactor performance increases at higher pressures. The results suggest that this SOFC system is an excellent reactor for $\mathrm{C} 2$ production and power generation simultaneously.

Wiyaratn et al. [97] evaluated chemicals and power cogeneration in an $\mathrm{Au} / \mathrm{LaSrMnO}_{3} / / \mathrm{YSZ} / / \mathrm{LaSrMnO}_{3} \mathrm{SOFC}$ reactor. The e.m.f. and closed-circuit current increased to $0.86 \mathrm{~V}$ and $9.8 \mathrm{~mA},\left(4.4 \mathrm{~mW} \mathrm{~cm}^{-2}\right)$ respectively at $850{ }^{\circ} \mathrm{C}$. The e.m.f. was also close to the theoretical value of oxidation of methane. A $7 \%$ methane conversion and a $5.7 \% \mathrm{C} 2$ hydrocarbons selectivity were observed when the air flow rate was $30 \mathrm{ml} / \mathrm{min}$ at $850^{\circ} \mathrm{C}$.

Some works were addressed to syngas production and electrical power generation from methane-fed SOFCs [98-101]. Syngas can be used as feedstock for hydrocarbon and methanol production. In particular, methane partial oxidation expressed by the following reaction:

$$
\mathrm{CH}_{4}+1 / 2 \mathrm{O}_{2} \rightarrow \mathrm{CO}+2 \mathrm{H}_{2}
$$

is attractive since it yields a synthesis gas with a molar ratio of 2 . Synthesis gas with molar ratio of $\mathrm{H}_{2}$ to $\mathrm{CO}$ of 2 is the most useful for the hydrocarbon and methanol synthesis. First, Yamada et al. [98] used a SOFC to obtain syngas by partial oxidation of methane. Co doped $\mathrm{La} 0.9 \mathrm{Sr}_{0.1} \mathrm{Ga}_{0} .8 \mathrm{Mg}_{0.2} \mathrm{O}_{3}$ was chosen as the electrolyte, since it was observed that doping small amount of Co was effective in increasing the oxide ion conductivity. The optimized composition for this electrolyte was $\mathrm{La} 0.9 \mathrm{Sr} 0.1 \mathrm{Ga} 0.8 \mathrm{Mg}_{0.115} \mathrm{Co}_{0.085} \mathrm{O}_{3}$ considering the power density and the amount of oxygen leakage. Although the thickness of electrolyte with the above composition was as thick as $0.5 \mathrm{~mm}$, a maximum power density and yield of synthesis gas were obtained at $242 \mathrm{~mW} \mathrm{~cm}^{-2}$ and $16 \%$, respectively at $800{ }^{\circ} \mathrm{C}$.

Then, Ishihara et al. [99] investigated the co-generation of syngas and electricity by using a single planar type SOFC. The electrolyte is a $\mathrm{LaGaO}_{3}$-based oxide. $\mathrm{La}_{0.6 \mathrm{Sr} 0.4 \mathrm{CoO}_{3}}$ and $\mathrm{Ni}$ were used as the cathode and the anode, respectively. A gaseous mixture of $\mathrm{CH}_{4}$ 
and $\mathrm{N}_{2}$ was employed as the fuel, while $\mathrm{O}_{2}$ was used as the oxidant. The SOFC gave at $1000 \circ \mathrm{C}$ a maximum power density of $526 \mathrm{mWcm}^{-2}$, which could be higher depending on doping, increasing the oxide ion conductivity. It was observed that doping $\mathrm{LaGaO}_{3}$ based oxide with small amount of Fe or Co was highly effective for increasing oxide ion conductivity. Thus, the use of Fe or $\mathrm{Co}$ doped $\mathrm{LaGaO}_{3}$ as electrolytes in SOFCs for methane partial oxidation would increase the power density and the yield of synthesis gas. The yield of synthesis gas was around $20 \%$ in all the cases studied.

Sobyanin and Belyaev[100] investigated methane-to-syngas oxidation and power generation over $\mathrm{Pt}$ electrodes in an SOFC reactor. The experiment was performed at a constant ratio of methane and oxygen flows $\left(\mathrm{CH}_{4} / \mathrm{O}_{2} \approx 1.8\right)$, so that an increase in methane flow rate was equivalent to an increase in the current (oxygen flow). Syngas productivity increases linearly with the increase of $\mathrm{CH}_{4}$ flow rate (or current), whereas electric power passes through maximum. Zhang et al. [101] carried out the partial oxidation of methane to syngas at $700-800{ }^{\circ} \mathrm{C}$ in a SOFC with an Ni-SDC anode and an Sr- and Mg-doped lanthanum gallate in the composition $\mathrm{La} 0.9 \mathrm{Sr}_{0.1} \mathrm{Ga}_{0.8} \mathrm{Mg}_{0.2} \mathrm{O}_{3-\delta}$ (LSGM) electrolyte. They observed that the co-generated syngas at $\mathrm{H}_{2} / \mathrm{CO}$ ratio of 1.4-2.0 varied with applied current densities, $\mathrm{CH}_{4}$ flow rates and operating temperatures. The cell voltage at $100 \mathrm{~mA} \mathrm{~cm}^{-2}$ and $800{ }^{\circ} \mathrm{C}$ was $0.90 \mathrm{~V}$, i.e. about $90 \mathrm{~mW} \mathrm{~cm}{ }^{-2}$ power density could be obtained. The cell operating at $50 \mathrm{~mA} \mathrm{~cm}^{-2}$ for $24 \mathrm{~h}$ almost showed no degradation of the cell performance.

Zhan et al. [102] used direct-methane SOFC (air,LSM-YSZIYSZINi-YSZ,CH4) for power and syngas production simultaneously. Thermodynamic equilibrium analysis indicated that efficient methane conversion to syngas takes place for SOFC operating temperature $>700{ }^{\circ} \mathrm{C}$ and $\mathrm{O}^{2-} / \mathrm{CH}_{4}$ ratios of $\approx 1$. Fuel cells operated at $T \approx 750{ }^{\circ} \mathrm{C}, V \approx 0.4 \mathrm{~V}$, and $\mathrm{O}^{2-} / \mathrm{CH}_{4} \approx 1.2$ yielded electrical power output of $\sim 700 \mathrm{~mW} \mathrm{~cm}^{-2}$ and syngas production rates of $\sim 20 \mathrm{sccm} \mathrm{cm}^{-2}$. Stable cell operation without coking for $>300 \mathrm{~h}$ was observed.

Pillai et al. [103] used direct-methane SOFCs to produce electricity and syngas. During initial operation at $750{ }^{\circ} \mathrm{C}$, the cells produced $900 \mathrm{~mW} \mathrm{~cm}^{-2}$ and $\approx 90 \%$ methane conversion to syngas at a rate of $30 \mathrm{sccm} / \mathrm{cm}^{2}$. However, the methane conversion decreased continuously over the first 30-40 h of operation, even though the solid oxide fuel cells (SOFC) electrical performance was stable. An additional catalyst layer on the anode yielded more stable methane conversion to syngas. Finally, the possibility of synthesis gas and power production from partial oxidation of $\mathrm{CH}_{4}$ in $\mathrm{SOFC}$ was studied by Paloukis et al. through a numerical simulation [104]. By using a simple mathematical model, they showed the technological potentiality to cogenerate synthesis gas and electricity through the autothermal operation of an SOFC and its high performance with overall thermodynamic efficiency far above unity. This can be obtained by the SOFC operating under transient conditions by periodically reversing the flow through the monolithic reactor. Thus, the energy can be accumulated and trapped inside the reactor, maintaining the reactor at high temperatures (above the adiabatic temperature rise): in this way the electrochemical partial oxidation of methane into synthesis gas can proceed autothermally.

Brousas et al. [105] compared a regular SOFC plant (complete oxidation of methane to $\mathrm{CO}_{2}$ and $\mathrm{H}_{2} \mathrm{O}$ ) with co-generation SOFC plants, producing ethylene and syngas. They observed that the rate of return for the regular fuel cell exceeded $25 \%$, whereas that for the ethylene plant was about $21 \%$, and that for the syngas plant was well behind at about $17 \%$.

\section{6. $\mathrm{CH}_{4} / \mathrm{CO}_{2}$ MIXTURES}

$\mathrm{CO}_{2}$ and $\mathrm{CH}_{4}$ largely contribute to the greenhouse effect. Conversely, conversion of $\mathrm{CH}_{4}$ into syngas using $\mathrm{CO}_{2}$ not only provides a useful feedstock for hydrocarbon and methanol synthesis but also contributes to the mitigation of greenhouse gases. The dry reforming of $\mathrm{CH}_{4}$ with $\mathrm{CO}_{2}$, an endothermic reaction $\left(\mathrm{CO}_{2}+\mathrm{CH}_{4}=2 \mathrm{CO}+2 \mathrm{H}_{2}\right)$, is a viable method to convert $\mathrm{CH}_{4}$ into syngas. Commonly, SOFCs directly convert the chemical energy of the fuels into electricity with $\mathrm{H}_{2} \mathrm{O}$ and $\mathrm{CO}_{2}$ as the products, which is very promising in terms of the energy efficiency yet leads to $\mathrm{CO}_{2}$ emission in practice. 
On the other hand, SOFCs are able to perform in situ $\mathrm{CO}_{2}-\mathrm{CH}_{4}$ reforming and $\mathrm{H}_{2}$ selective electro-oxidation, enabling a sustainable path to produce electrical power and syngas from $\mathrm{CO}_{2} \mathrm{CH}_{4}$ mixtures. Hua et al. [106] developed an innovative $\mathrm{CH}_{4}-\mathrm{CO}_{2}$ dry reforming process to co-produce electricity and $\mathrm{CO}$-concentrated syngas, which benefits the selective oxidation of $\mathrm{H}_{2}$ in high performance proton-conducting solid oxide fuel cells (H-SOFCs). An additional layer, consisting of a Nio.8Co0.2-La0.2 $\mathrm{Ce}_{0.8 \mathrm{O}} \mathrm{O}_{1.9}$ (NiCo-LDC) composite, was incorporated into the anode support, forming a layered SOFC configuration. The multiple-twinned bimetallic nanoparticles showed enhanced activity towards in situ methane dry reforming. Compared to the conventional cell design, this layered SOFC demonstrated drastically improved $\mathrm{CO}_{2}$ resistance as well as internal reforming efficiency $\left(\mathrm{CO}_{2}\right.$ conversion reached $91.5 \%$ at $\left.700{ }^{\circ} \mathrm{C}\right)$, and up to $100 \mathrm{~h}$ galvanostatic stability in a $\mathrm{CH}_{4}-$ $\mathrm{CO}_{2}$ feedstream at $1 \mathrm{~A} \mathrm{~cm}^{-2}$. More importantly, $\mathrm{H}_{2}$ was effectively and exclusively converted by electrochemical oxidation, yielding no $\mathrm{CO}_{2}$ but $\mathrm{CO}$ concentrated syngas in the anode effluent. The maximum power density exceeded $910 \mathrm{~mW} \mathrm{~cm}^{-2}$ at $700{ }^{\circ} \mathrm{C}$. The heat released by $\mathrm{H}_{2}$ electrochemical oxidation fully compensated for that required by the extremely endothermic dry reforming reaction, making the entire process thermally selfsufficient. Moreover, the layered structure was beneficial in terms of decreasing coking and increasing $\mathrm{CO}_{2}$ resistance of the SOFC in the mixed $\mathrm{CO}_{2}$ and $\mathrm{CH}_{4}$ feedstock. Summarizing, this $\mathrm{H}-\mathrm{SOFC}$ showed outstanding electrochemical performances in $\mathrm{CH}_{4}-\mathrm{CO}_{2}$ feedstream, coproducing $\mathrm{CO}$-enriched syngas with few $\mathrm{CO}_{2}$ by-products.

Chen et al. [107] developed a multi-physical model to investigate the dry methane reforming (DMR) integrated SOFC running on $\mathrm{CH}_{4}$ and $\mathrm{CO}_{2}$ mixture to obtain the cogeneration of syngas/power. From the base case simulations at SOFC voltage of OCV and $0.7 \mathrm{~V}$, they observed that the integration of proton conducting SOFC at $0.7 \mathrm{~V}$ could effectively enhance the syngas production than the $\mathrm{OCV}$ condition (4.8\% improvement for $\mathrm{CO}_{2}$ conversion and $21.6 \%$ for $\mathrm{CH}_{4}$ conversion) and generate electricity $(1.5 \mathrm{~W})$ at the same time. The decrease of the voltage leads to higher electricity output, higher syngas production efficiency, and lower $\mathrm{H}_{2}: \mathrm{CO}$ ratio of the product. However, the operating voltage is suggested to be higher than $0.5 \mathrm{~V}$ to prevent the undesired large temperature gradient. The inlet fuel flow rate showed a significant influence on the $\mathrm{CO}_{2}$ and $\mathrm{CH}_{4}$ conversion ratio.

The increase of flow rate gave rise to a low $\mathrm{H}_{2}$ fraction, reducing the current density, and thus the temperature in DMR-SOFC. A collection of literature data on methane-fueled fuel cells including intrinsic parameters (catalysts and electrolyte), operational parameters (fuel composition and temperature), produced chemicals and maximum power density (MPD) values is reported in Table 1.

Table 1. A collection of literature data on methane-fueled fuel cells including intrinsic parameters (catalysts and electrolyte), operational parameters (fuel composition and temperature), produced chemicals and maximum power density.

\begin{tabular}{|c|c|c|c|c|c|c|c|}
\hline Fuel Cell Type & $\begin{array}{l}\text { Anode // } \\
\text { cathode }\end{array}$ & $\begin{array}{l}\text { Methane } \\
\text { input }\end{array}$ & Eletrolyte & $\mathbf{T} /{ }^{\circ} \mathrm{C}$ & Chemicals & $\begin{array}{c}\mathbf{M P D}^{[\mathbf{a}]} \\
/ \mathbf{m W} \mathbf{c m}^{-2}\end{array}$ & Ref \\
\hline $\mathrm{PEMFC}^{[\mathrm{b}]}$ & $\begin{array}{c}\mathrm{Pd} / \mathrm{C} / / \mathrm{Pt} / \mathrm{C} \\
\mathrm{Pd}_{10 \%} \mathrm{Au}_{(10 \%)} \\
/ \mathrm{C} / / \mathrm{Pt} / \mathrm{C}\end{array}$ & Anode & $\begin{array}{c}\text { Phosphoric acid } \\
\text { doped Nafion mem- } \\
\text { brane }\end{array}$ & 110 & - & $\begin{array}{l}0.8 \\
2.5\end{array}$ & {$[80]$} \\
\hline PEMFC & $\mathrm{Pd} / \mathrm{C} / / \mathrm{Pt} / \mathrm{C}$ & Anode $+\mathrm{H}_{2} \mathrm{O}_{(\mathrm{g})}$ & Nafion & 80 & Formate & 0.55 & {$[47]$} \\
\hline PEMFC & $\mathrm{PdZn} / \mathrm{C} / / \mathrm{Pt} / \mathrm{C}$ & Anode $+\mathrm{H}_{2} \mathrm{O}_{(\mathrm{g})}$ & Nafion & 80 & $\begin{array}{l}\text { Methanol, } \\
\text { formate, formic } \\
\text { acid }\end{array}$ & 0.6 & {$[81]$} \\
\hline PEMFC & $\begin{array}{c}\mathrm{PdAu} / \mathrm{C} / / \\
\mathrm{Pt} / \mathrm{C}\end{array}$ & Anode $+\mathrm{H}_{2} \mathrm{O}_{(\mathrm{g})}$ & Nafion & 80 & $\begin{array}{c}\text { Methanol, } \\
\text { formate, formic } \\
\text { acid }\end{array}$ & 1.0 & {$[82]$} \\
\hline PEMFC & $\begin{array}{l}\mathrm{Pt} / \mathrm{C} / / \\
\mathrm{PdAu} / \mathrm{C}\end{array}$ & $\begin{array}{c}\text { Cathode }+\mathrm{H}_{2} \mathrm{O} \\
\text { or } \mathrm{O}_{2}\end{array}$ & $\mathrm{Sn}_{0.9} \mathrm{In}_{0.1} \mathrm{P}_{2} \mathrm{O}_{7}$ & $50-250$ & Methanol and $\mathrm{CO}_{2}$ & - & {$[84]$} \\
\hline
\end{tabular}




\begin{tabular}{|c|c|c|c|c|c|c|c|}
\hline PEMFC & $\begin{array}{c}\mathrm{Pt} / \mathrm{C} / / \mathrm{Pd}- \\
\mathrm{Au}-\mathrm{Cu} / \mathrm{C}\end{array}$ & $\begin{array}{c}\text { Cathode }+\mathrm{H}_{2} \mathrm{O} \\
\text { or } \mathrm{O}_{2}\end{array}$ & $\mathrm{Sn}_{0.9} \mathrm{In}_{0.1} \mathrm{P}_{2} \mathrm{O}_{7}$ & $50-450$ & methanol & - & {$[108]$} \\
\hline PEMFC & $\mathrm{Pt} / \mathrm{C} / / \mathrm{Pt} / \mathrm{C}$ & Anode $+\mathrm{H}_{2} \mathrm{O}$ & $\mathrm{Sn}_{0.9} \mathrm{In}_{0.1} \mathrm{P}_{2} \mathrm{O}_{7}$ & $100-300$ & Methanol & - & [9] \\
\hline PEMFC & $\mathrm{Pt} / \mathrm{C} / / \mathrm{Pt} / \mathrm{C}$ & Cathode $+\mathrm{H}_{2} \mathrm{O}_{2}$ & Nafion & 80 & $\begin{array}{c}\text { Methanol, formic } \\
\text { acid and } \\
\text { formaldehyde }\end{array}$ & 70 & [86] \\
\hline AAEMFC ${ }^{[c]}$ & $\mathrm{Pt} / \mathrm{C} / / \mathrm{Pt} / \mathrm{C}$ & Anode $+\mathrm{KOH}$ & $\begin{array}{l}\mathrm{KOH} \text { doped Nafion } \\
\text { membrane }\end{array}$ & 25 & Methanol, formate & 0.3 & {$[58]$} \\
\hline AAEMFC & $\mathrm{PdNi} / \mathrm{C} / / \mathrm{Pt} / \mathrm{C}$ & Anode $+\mathrm{KOH}$ & $\begin{array}{l}\text { KOH doped Nafion } \\
\text { membrane }\end{array}$ & 25 & Methanol, formate & 0.13 & [87] \\
\hline AAEMFC & $\begin{array}{c}{\left[6,6^{\prime}-\left(2,2^{\prime}-\right.\right.} \\
\text { Bipyridine- } \\
6,6^{\prime}- \\
\text { Diyl)bis(1,3,5- } \\
\text { Triazine-2,4- } \\
\text { Diamine)](Nit } \\
\text { rato- } \\
\text { O)Copper(II) } \\
\text { Complex/C // } \\
\text { Pt/C }\end{array}$ & Anode $+\mathrm{KOH}$ & $\begin{array}{l}\text { KOH doped Nafion } \\
\text { membrane }\end{array}$ & 25 & Methanol, formate & - & {$[53]$} \\
\hline AAEMFC & $\mathrm{Pt} / \mathrm{Cu} / / \mathrm{Pt} / \mathrm{C}$ & Anode $+\mathrm{KOH}$ & $\begin{array}{l}\mathrm{KOH} \text { doped Nafion } \\
\text { membrane }\end{array}$ & 25 & Methanol, formate & 0.12 & [90] \\
\hline $\mathrm{SOFC}^{[\mathrm{d}]}$ & $\begin{array}{l}\mathrm{Pt} \text { or } \mathrm{Rh} / / \\
\mathrm{Pt} / \mathrm{C}\end{array}$ & Anode $+\mathrm{NH}_{3}$ & YSZ & $800-1000$ & $\mathrm{HCN}$ & 10 & [92] \\
\hline SOFC & $\begin{array}{c}\mathrm{Sm}_{2} \mathrm{O}_{3-} \\
\mathrm{LaSrMnO}_{2} / / \\
\mathrm{LaSrMnO}_{3} \\
\mathrm{Sr}_{\mathrm{La}_{2} \mathrm{O}_{3}-}\end{array}$ & Anode & YSZ & 760 & C2 hydrocarbons & - & [93] \\
\hline SOFC & $\begin{array}{c}\mathrm{Bi}_{2} \mathrm{O}_{3}-\mathrm{Ag} / / \\
\mathrm{Ag}\end{array}$ & Anode & YSZ & 730 & C2 hydrocarbons & 6 & [95] \\
\hline SOFC & $\begin{array}{c}\mathrm{Au} / \mathrm{LaSrMnO}_{3} \\
/ / \mathrm{LaSrMnO}_{3}\end{array}$ & Anode & YSZ & 850 & C2 hydrocarbons & 4.4 & [97] \\
\hline SOFC & $\begin{array}{c}\mathrm{Ni} / / \\
\mathrm{La}_{0.6} \mathrm{Sr}_{0.4} \mathrm{CoO}_{3}\end{array}$ & Anode $+\mathrm{N}_{2}$ & $\mathrm{LaGaO}_{3}$ & 1000 & Syngas & 526 & [99] \\
\hline SOFC & $\begin{array}{c}\mathrm{Ni}-\mathrm{SDC} / / \\
\mathrm{Sm}_{0.6} \mathrm{Sr}_{0.4} \mathrm{CoO} \\
3\end{array}$ & Anode & $\begin{array}{c}\mathrm{La}_{0.9} \mathrm{Sr}_{0.1} \mathrm{Ga}_{0.8} \mathrm{Mg}_{0.2} \mathrm{O} \\
3-\delta\end{array}$ & 800 & Syngas & 90 & {$[101]$} \\
\hline SOFC & $\begin{array}{c}\mathrm{Ni}-\mathrm{YSZ} / / \\
\mathrm{La}_{0.8} \mathrm{Sr}_{0.2} \mathrm{MnO} \\
3\end{array}$ & Anode & YSZ & 750 & Syngas & 700 & {$[102]$} \\
\hline H-SOFC & $\begin{array}{c}\mathrm{Ni} / / \mathrm{NdBa}_{0.75} \mathrm{C} \\
\mathrm{a}_{0.25} \mathrm{Co}_{2} \mathrm{O}_{5+\mathrm{d}} \\
\end{array}$ & Anode $+\mathrm{CO}_{2}$ & $\begin{array}{c}\mathrm{BaZr}_{0.1} \mathrm{Ce}_{0.7} \mathrm{Y}_{0.1} \mathrm{Yb}_{0.1} \\
\mathbf{O}_{3-\mathrm{d}}\end{array}$ & 700 & $\begin{array}{c}\text { CO-enriched } \\
\text { syngas }\end{array}$ & 910 & {$[106]$} \\
\hline
\end{tabular}

[a] Maximum Power density. [b] proton exchange membrane fuel cell [c] alkaline anion exchange membrane fuel cell [d] solid oxide fuel cell.

\section{MATERIALS FOR METHANE PARTIAL OXIDATION REACTION}

The activation of methane is influenced by the characteristics of the catalysts, such as surface, structure, and composition. Transition metal oxides are the most commonly used in the conversion of methane-to-methanol [14, 109].

The surface-catalyzed activation of $\mathrm{C}-\mathrm{H}$ bonds of methane for its selective oxidative coupling into ethane and ethylene or for its partial oxidation into methanol and formaldehyde is a subject of increasing interest. Many metal oxides have been claimed to be effective catalysts for these direct conversions of methane into the functionalized chemicals.

Nickel is a frequently used metal catalyst for methane conversion due to its availability and low cost. There are different strategies for stabilizing Ni particles in catalytic reactions against coking and sintering. Some of them include modifications of Ni particles by addition of a second metal, such as Co or Cu. Nematollahi and Neyts [110] by density functional theory (DFT) computations compared the reaction and activation energies of 
$\mathrm{Ni}$ and $\mathrm{NiN}_{4}$ embedded graphene on the methane-to-methanol conversion near room temperature. Thermodynamically, conversion of methane to methanol is energetically favorable at ambient conditions. Santos and co-workers [58] attributed the conversion of methane to methanol on a $\mathrm{NiO}$ catalyst in a solid electrolyte reactor - alkaline fuel cell type to the low potential for water activation, behavior not observed for $\mathrm{Pt}$ or Pd. Their oxides were appointed as a site for methane adsorption and activation [85].

Platinum is one of the most efficient catalysts used in the oxidation of small organic molecules due to its excellent catalytic properties. When considering the electrochemical properties of $\mathrm{Pt}$, it should be remembered that $\mathrm{Pt}$ surface structure alters the rate of adsorption and oxidation of the adsorbed molecules [48, 69, 111], i.e., terraces on Pt (100) can active $\mathrm{C}-\mathrm{H}$ bond at low energy [112]. Hsieh and Chen [113] studied Pt black for methane oxidation to $\mathrm{CO}_{2}$ and report the shift of onset potential for methane oxidation in function of $\mathrm{pH}$.

Boyd and co-workers [48] found platinum to be the most active catalyst for the electrochemical oxidation of methane under ambient conditions. To understand the reaction mechanism and the factors that determine catalyst activity, they used experimental and theorical studies and found that methane activation step is thermochemical (i.e., $\mathrm{CH} 4$ (g) $\rightarrow$ $\mathrm{CH}^{*}+\mathrm{H}^{*}$ ). Nandenha et al. [86] used a Pt cathode catalyst in a solid electrolyte reactor - fuel cell type to activate $\mathrm{H}_{2} \mathrm{O}_{2}$ species and convert methane to methanol.

The catalytic activity of palladium can be enhanced by supporting it on carbon materials. Carbon materials such as carbon nanotubes (CNTs), activated carbon (AC), and reduced graphene oxide ( $\mathrm{rGO}$ ) were employed as the catalyst support, and palladiumgold (Pd-Au) nanoparticles were used as active center. The Pd-Au/CNTs catalyst showed outstanding methanol productivity and selectivity [111]. Compared with the PdAu/CNTs, $\mathrm{Pd}-\mathrm{Au}$ supported on functionalized carbon nanotubes (CNTs-n) by a treatment of nitric acid enhances the methanol selectivity, but decreases the methanol productivity [73].

Serra-Maia and co-workers [109] observed that methane oxidation to methanol occurs in a significant excess of hydrogen peroxide by inhibiting the activity of AuPd nanocatalysts. Jin and co-workers [114] reported a catalyst system formed by $\mathrm{Pd}$ and $\mathrm{Au}$ strengthened by hydrophobically covered zeolite, to generate hydrogen peroxide for immediate reaction with methane at mild temperatures. Santos and co-workers attributed the Pd activity for methanol electrosynthesis to the formation of a thin layer of PdO on the catalytic surface [58].

The methane activation with in-situ $\mathrm{H}_{2} \mathrm{O}_{2}$ formation was successfully demonstrated in a microcapillary containing Au-Pd nanoparticles embedded in its silica-coated walls using a microchannel reactor. The direct methane activation with in situ generation of $\mathrm{H}_{2} \mathrm{O}_{2}$ promoted methanol formation $[32,66]$. The high affinity for oxygen of gold facilitates the breakdown of $\mathrm{H}_{2} \mathrm{O}_{2}$ in $\mathrm{OH} \bullet$, which would be the activator of the $\mathrm{C}-\mathrm{H}$ breakage $[73,115,116]$.

A bifuncional catalyst, with a carbophilic site and sites capable of activating water, as exemplified in figure 5 can be used for maximize the conversion of the hydrocarbon into products, as a cited by Godoi [90].

A screening of different metal oxides for the oxidative coupling of methane (OCM) by lattice oxygen, using first and second transition metal oxides ( $, \mathrm{Cr}, \mathrm{Co}, \mathrm{Cu}, \mathrm{Zr}$ and Mo) and some lanthanide oxides (La and Ce) was carried out by Hassan and co-workers [71] . The OCM activity was correlated with the surface amount of a low 1s binding energy $(\mathrm{O} 1 \mathrm{~s}, 526-527 \mathrm{eV})$ oxygen species on the catalyst, as well as its energy separation from the lattice oxygen.

Iron is extensively applied as a catalyst for the conversion of methane to formaldehyde [117], however, mild conditions make it more selective for less oxidized products such as methanol [118]. Yang et al [6], in a study of visible-light-driven selective oxidation of methane to methanol on amorphous FeOOH coupled $\mathrm{m}-\mathrm{WO}_{3}$, reported the active role of Fe in the $\mathrm{H}_{2} \mathrm{O}_{2}$ decomposition mechanism. The same role was attributed to Fe by Zuo et al[119] in a study about selective oxidation of methane with $\mathrm{H}_{2} \mathrm{O}_{2}$ over Fe-silicalite-1. 
Copper is active for partial oxidation of methane into methanol, due to its high activity for water dissociation at $177-227{ }^{\circ} \mathrm{C}$, a key process to $\mathrm{C}-\mathrm{H}$ break [120], and the direct conversion increases in the presence of zeolites [14].

Sushkevich and co-workers[25] studied methane oxidation over copper-exchanged zeolites via chemical looping. Methoxy species and carbon monoxide are the primary reaction products formed directly from methane. Partial poisoning with water after the oxygen activation and before the methane reaction leads to the decrease of methanol yield, which is associated with the blockage of at least two copper atoms in the active site per one water molecule. In addition, they found that the poisoning is reversible and the increase in methane pressure increases CuMOR (copper mordenite) activity due to competitive adsorption on active sites. Alvarez and coworkers[19] also studied the partial oxidation of methane to methanol over a Cu-MOR catalyst at $200{ }^{\circ} \mathrm{C}$. They observed that at the optimum reaction conditions $52 \%$ of the adsorbed methane is converted to methanol. Metal organic frameworks (MOFs) are a class of hybrid crystalline materials, composed of metal ions/clusters linked together by organic ligands [121] which have a high surface area, microporosity that would act as reaction zones, limiting the residence time of the molecules of interest in the catalytic site, making the reaction more specific [122]. These materials have been applied for methane oxidation: Garcia et al. [53] used a [6,6'-(2,2'Bipyridine-6,6'-Diyl)bis(1,3,5-Triazine-2,4-Diamine)](Nitrato-O)Coppe $r(\mathrm{II})$ complex for the cogeneration of chemicals and power from methane.

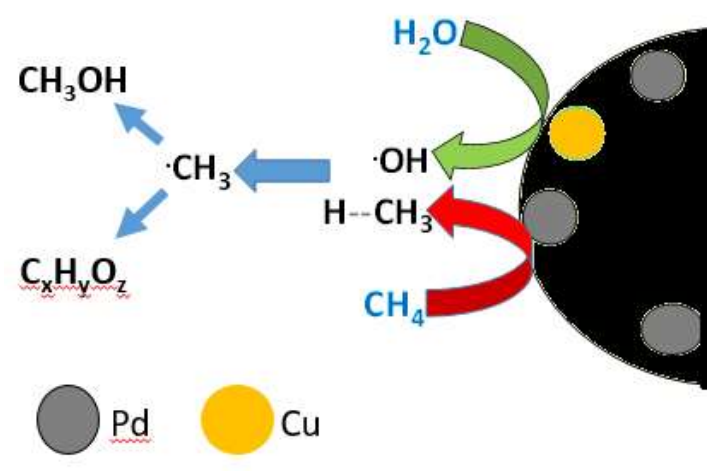

Figure 5. Partial methane oxidation with bifunctional $\mathrm{PdCu} / \mathrm{C}$ electrocatalyst.

Another material very active for water dissociation is ceria[120]; this oxide also acts as an oxygen buffer [123] in a thermoprocess. Lustemberg et al. [123] showed that low-loaded $\mathrm{Ni} / \mathrm{CeO}_{2}(111)$ system activates $\mathrm{CH}_{4}$ at $25{ }^{\circ} \mathrm{C}$ and then, with the help of water, which prevents sequential cleavage of $\mathrm{C}-\mathrm{H}$ bonds and at $177^{\circ} \mathrm{C}$ methanol was obtained with a conversion of about $35 \%$.

Metal-exchanged zeolite has been reported as efficient catalyst to partial oxidation of methane to methanol using only oxygen and water at low temperatures [62, 124]. Kang and co-workers carried out selective oxidation of methane into methane oxygenates, including methanol and formic acid, over Fe-zeolites and Pd/activated carbon in the presence of molecular hydrogen as a reducing agent using a liquid-phase with molecular oxygen[125].

Kang and co-workers. [125] observed the partial oxidation of methane using Fe-zeolites prepared via an ion-exchange method to immobilize the homogeneous Fe catalysts into the zeolite matrix. Rocha et al [42] applied the bismuth vanadate $\left(\mathrm{BiVO}_{4}\right)$ microcrystals for conversion of methane preferencially in methanol, explaind that this selectivity is echoed in reports for the same reaction via photocatalyzed pathways.

\section{OPPORTUNITIES AND OUTLOOK}


This review highlighted the ability of fuel cells to convert the chemical energy of methane in valuable chemicals and electric power. Also if it is an interesting field related to the commercial development of fuel cells, few works are present in the literature. Although knowledge has been obtained on different types of electrocatalytic systems capable of catalyzing the selective conversion of methane, the tailoring of electrocatalytic systems for methane conversion to value-added chemicals such as $\mathrm{C} 2$ compounds and methanol with high efficiency and high selectivity still remains a challenge. An improvement of catalyst activity and stability and reduced cost of catalysts are a challenge in fuel cell reactors for opening the opportunity in commercialization. Moreover, as SOFCs are operated at $800-1000{ }^{\circ} \mathrm{C}$, materials with high activity and stability at high temperatures are required. Thus, a development of anode catalysts for an oxidative coupling of methane in SOFC becomes an important goal to improve the conversion, selectivity, yield and stability of the reactor. For example, it is necessary to develop suitable catalysts capable of generating reactive oxygen species to activate the conversion of methane to methanol with a low over-potential and a high current at the same time. The understanding into the active sites and phases resulting from the selective oxidation or oxidative coupling of methane are useful to develop more efficient catalysts for the electrocatalytic methane conversion. However, a deep knowledge into the roles of electrochemical reaction environments in the conversion of methane and the formation of products are still lacking.

Economic studies showed that exothermic reactions involving inexpensive raw materials and products with respect to the cost of electricity are good candidates for electrocogeneration. Different electrocogeneration processes have been identified to be interesting from a commercial point of view. Further studies in such fields are desirable because the advantage of different electrocogeneration processes depend on the relative value of chemicals to power of the historical moment, with probable better suitability than in chemical or electrolytic reactors.

Acknowledgments: We are grateful to CAPES, CNPq (302709/2020-7), FAPESP (2017/11937-4) and CINE-SHELL (ANP) for financial supports.

\section{REFERENCES}

[1] J.-P. Lange, V.L. Sushkevich, A.J. Knorpp, J.A. van Bokhoven, Methane-to-Methanol via Chemical Looping: Economic Potential and Guidance for Future Research, Industrial \& Engineering Chemistry Research 58(20) (2019) 8674-8680.

[2] J. Jang, K. Shen, C.G. Morales-Guio, Electrochemical Direct Partial Oxidation of Methane to Methanol, Joule 3(11) (2019) 25892593.

[3] S.I. Chan, S.S.F. Yu, C.-C. Liu, C.-Y. Mou, Selective oxidation of light alkanes under mild conditions, Current Opinion in Green and Sustainable Chemistry 22 (2020) 39-46.

[4] H. Blanco, W. Nijs, J. Ruf, A. Faaij, Potential of Power-to-Methane in the EU energy transition to a low carbon system using cost optimization, Applied Energy 232 (2018) 323-340.

[5] D. Li, R. Xu, Z. Gu, X. Zhu, S. Qing, K. Li, Chemical-Looping Conversion of Methane: A Review, Energy Technology 8(8) (2020) 1900925.

[6] J. Yang, J. Hao, J. Wei, J. Dai, Y. Li, Visible-light-driven selective oxidation of methane to methanol on amorphous FeOOH coupled m-WO3, Fuel 266 (2020) 117104.

[7] D. San-José-Alonso, J. Juan-Juan, M.J. Illán-Gómez, M.C. Román-Martínez, Ni, Co and bimetallic Ni-Co catalysts for the dry reforming of methane, Applied Catalysis A: General 371(1) (2009) 54-59.

[8] R. Shavi, V. Hiremath, J.G. Seo, Radical-initiated oxidative conversion of methane to methanol over metallic iron and copper catalysts, Molecular Catalysis 445 (2018) 232-239.

[9] B. Lee, T. Hibino, Efficient and selective formation of methanol from methane in a fuel cell-type reactor, Journal of Catalysis 279(2) (2011) 233-240.

[10] S. Xie, S. Lin, Q. Zhang, Z. Tian, Y. Wang, Selective electrocatalytic conversion of methane to fuels and chemicals, Journal of Energy Chemistry 27(6) (2018) 1629-1636.

[11] S.C. Nimkar, R.K. Mewada, M.A. Rosen, Exergy and exergoeconomic analyses of thermally coupled reactors for methanol synthesis, International Journal of Hydrogen Energy 42(47) (2017) 28113-28127.

[12] S. Kim, M. Kim, Y.T. Kim, G. Kwak, J. Kim, Techno-economic evaluation of the integrated polygeneration system of methanol, power and heat production from coke oven gas, Energy Conversion and Management 182 (2019) 240-250.

[13] M.R. Antoniewicz, Synthetic methylotrophy: Strategies to assimilate methanol for growth and chemicals production, Current Opinion in Biotechnology 59 (2019) 165-174. 
[14] R. Sharma, H. Poelman, G.B. Marin, V.V. Galvita, Approaches for Selective Oxidation of Methane to Methanol, Catalysts 10(194) (2020).

[15] J. Sehested, Industrial and scientific directions of methanol catalyst development, Journal of Catalysis 371 (2019) 368-375.

[16] C. Smith, A.K. Hill, L. Torrente-Murciano, Current and future role of Haber-Bosch ammonia in a carbon-free energy landscape, Energy \& Environmental Science 13(2) (2020) 331-344.

[17] C. Karakaya, R.J. Kee, Progress in the direct catalytic conversion of methane to fuels and chemicals, Progress in Energy and Combustion Science 55 (2016) 60-97.

[18] A.S. Ramos, M.C.L. Santos, C.M. Godoi, A. Oliveira Neto, R.F.B. De Souza, Obtaining C2 and C3 Products from Methane Using $\mathrm{Pd} / \mathrm{C}$ as Anode in a Solid Fuel Cell-type Electrolyte Reactor, ChemCatChem 12(18) (2020) 4517-4521.

[19] M. Álvarez, P. Marín, S. Ordóñez, Direct oxidation of methane to methanol over Cu-zeolites at mild conditions, Molecular Catalysis 487 (2020) 110886.

[20] P. Tomkins, M. Ranocchiari, J.A. van Bokhoven, Direct Conversion of Methane to Methanol under Mild Conditions over CuZeolites and beyond, Accounts of Chemical Research 50(2) (2017) 418-425.

[21] J. Zhu, V.L. Sushkevich, A.J. Knorpp, M.A. Newton, S.C.M. Mizuno, T. Wakihara, T. Okubo, Z. Liu, J.A. van Bokhoven, CuErionite Zeolite Achieves High Yield in Direct Oxidation of Methane to Methanol by Isothermal Chemical Looping, Chem. Mater. 32(4) (2020) 1448-1453.

[22] T. Ikuno, J. Zheng, A. Vjunov, M. Sanchez-Sanchez, M.A. Ortuño, D.R. Pahls, J.L. Fulton, D.M. Camaioni, Z. Li, D. Ray, B.L. Mehdi, N.D. Browning, O.K. Farha, J.T. Hupp, C.J. Cramer, L. Gagliardi, J.A. Lercher, Methane Oxidation to Methanol Catalyzed by Cu-Oxo Clusters Stabilized in NU-1000 Metal-Organic Framework, Journal of the American Chemical Society 139(30) (2017) 10294-10301.

[23] J.G. Vitillo, A. Bhan, C.J. Cramer, C.C. Lu, L. Gagliardi, Quantum Chemical Characterization of Structural Single Fe(II) Sites in MIL-Type Metal-Organic Frameworks for the Oxidation of Methane to Methanol and Ethane to Ethanol, ACS Catalysis 9(4) (2019) 2870-2879.

[24] H.A. Doan, Z. Li, O.K. Farha, J.T. Hupp, R.Q. Snurr, Theoretical insights into direct methane to methanol conversion over supported dicopper oxo nanoclusters, Catalysis Today 312 (2018) 2-9.

[25] V.L. Sushkevich, J.A. van Bokhoven, Kinetic study and effect of water on methane oxidation to methanol over copper-exchanged mordenite, Catalysis Science \& Technology 10(2) (2020) 382-390.

[26] H. Dalton, The Leeuwenhoek Lecture 2000 The natural and unnatural history of methane-oxidizing bacteria, Philosophical Transactions of the Royal Society B: Biological Sciences 360(1458) (2005) 1207-1222.

[27] R. Serra-Maia, F.M. Michel, Y. Kang, E.A. Stach, Decomposition of Hydrogen Peroxide Catalyzed by AuPd Nanocatalysts during Methane Oxidation to Methanol, ACS Catalysis 10(9) (2020) 5115-5123.

[28] H.W. Lee, H.T. Dang, H. Kim, U. Lee, J.-M. Ha, J. Jae, M. Cheong, H. Lee, Pt black catalyzed methane oxidation to methyl bisulfate in H2SO4-SO3, Journal of Catalysis 374 (2019) 230-236.

[29] K. Kvande, D.K. Pappas, E. Borfecchia, K.A. Lomachenko, Advanced X-ray Absorption Spectroscopy Analysis to Determine Structure-Activity Relationships for Cu-Zeolites in the Direct Conversion of Methane to Methanol, ChemCatChem 12(9) (2020) 2385-2405.

[30] Y. Zeng, H.C. Liu, J.S. Wang, X.Y. Wu, S.L. Wang, Synergistic photocatalysis-Fenton reaction for selective conversion of methane to methanol at room temperature, Catalysis Science \& Technology 10(8) (2020) 2329-2332.

[31] C. Ridruejo, F. Alcaide, G. Alvarez, E. Brillas, I. Sires, On-site H2O2 electrogeneration at a CoS2-based air-diffusion cathode for the electrochemical degradation of organic pollutants, Journal of Electroanalytical Chemistry 808 (2018) 364-371.

[32] A. Delparish, S. Kanungo, J. van der Schaaf, M.F. Neira d'Angelo, Towards coupling direct activation of methane with in situ generation of H2O2, Catal. Sci. Technol. 9(18) (2019) 5142-5149.

[33] A. Ho, C. Lüke, Z. Cao, P. Frenzel, Ageing well: methane oxidation and methane oxidizing bacteria along a chronosequence of 2000 years, Environmental Microbiology Reports 3(6) (2011) 738-743.

[34] R.H. Morris, Methane activation by a single copper center in particulate methane monooxygenase: A computational study, Inorganica Chimica Acta 503 (2020) 119441.

[35] S. Sun, Y.-C. Zhang, G. Shen, Y. Wang, X. Liu, Z. Duan, L. Pan, X. Zhang, J.-J. Zou, Photoinduced composite of Pt decorated $\mathrm{Ni}(\mathrm{OH}) 2$ as strongly synergetic cocatalyst to boost $\mathrm{H} 2 \mathrm{O}$ activation for photocatalytic overall water splitting, Applied Catalysis B: Environmental 243 (2019) 253-261.

[36] J. Kiss, A. Kukovecz, Z. Konya, Beyond Nanoparticles: The Role of Sub-nanosized Metal Species in Heterogeneous Catalysis, Catal. Lett. 149(6) (2019) 1441-1454.

[37] Á. López-Martín, A. Caballero, G. Colón, Photochemical methane partial oxidation to methanol assisted by H2O2, Journal of Photochemistry and Photobiology A: Chemistry 349 (2017) 216-223.

[38] S. Shi, Z. Sun, C. Bao, T. Gao, Y.H. Hu, The special route toward conversion of methane to methanol on a fluffy metal-free carbon nitride photocatalyst in the presence of H2O2, Int. J. Energy Res. 44(4) (2020) 2740-2753.

[39] Y. Li, J. Li, G. Zhang, K. Wang, X. Wu, Selective Photocatalytic Oxidation of Low Concentration Methane over Graphitic Carbon Nitride-Decorated Tungsten Bronze Cesium, ACS Sustainable Chem. Eng. 7(4) (2019) 4382-4389.

[40] M. Yan, Y. Kawamata, P.S. Baran, Synthetic Organic Electrochemical Methods Since 2000: On the Verge of a Renaissance, Chemical Reviews 117(21) (2017) 13230-13319.

[41] D.E. Blanco, B. Lee, M.A. Modestino, Optimizing organic electrosynthesis through controlled voltage dosing and artificial intelligence, Proceedings of the National Academy of Sciences 116(36) (2019) 17683-17689. 
[42] R.S. Rocha, R.M. Reis, M.R.V. Lanza, R. Bertazzoli, Electrosynthesis of methanol from methane: The role of V2O5 in the reaction selectivity for methanol of a TiO2/RuO2/V2O5 gas diffusion electrode, Electrochimica Acta 87 (2013) 606-610.

[43] Z. Zakaria, S.K. Kamarudin, Direct conversion technologies of methane to methanol: An overview, Renewable and Sustainable Energy Reviews 65 (2016) 250-261.

[44] S.S. Dhiman, N. Shrestha, A. David, N. Basotra, G.R. Johnson, B.S. Chadha, V. Gadhamshetty, R.K. Sani, Producing methane, methanol and electricity from organic waste of fermentation reaction using novel microbes, Bioresource Technology 258 (2018) 270-278.

[45] J.A. Arminio-Ravelo, M. Escudero-Escribano, Strategies towards the sustainable electrochemical oxidation of methane to methanol, Current Opinion in Green and Sustainable Chemistry (2021) 100489.

[46] M. Sustersic, W. Triaca, A. Arvía, The electrosorption of methane and its potentiodynamic electrooxidation on platinized platinum, Journal of the Electrochemical Society 127(6) (1980) 1242.

[47] J. Nandenha, E.H. Fontes, R.M. Piasentin, F.C. Fonseca, A.O. Neto, Direct oxidation of methane at low temperature using Pt/C, $\mathrm{Pd} / \mathrm{C}, \mathrm{Pt} / \mathrm{C}-\mathrm{ATO}$ and $\mathrm{Pd} / \mathrm{C}-\mathrm{ATO}$ electrocatalysts prepared by sodium borohydride reduction process, Journal of Fuel Chemistry and Technology 46(9) (2018) 1137-1145.

[48] M.J. Boyd, A.A. Latimer, C.F. Dickens, A.C. Nielander, C. Hahn, J.K. Nørskov, D.C. Higgins, T.F. Jaramillo, Electro-Oxidation of Methane on Platinum under Ambient Conditions, ACS Catalysis 9(8) (2019) 7578-7587.

[49] F. Hahn, C.A. Melendres, Anodic oxidation of methane at noble metal electrodes: an 'in situ' surface enhanced infrared spectroelectrochemical study, Electrochimica Acta 46(23) (2001) 3525-3534.

[50] L. Arnarson, P.S. Schmidt, M. Pandey, A. Bagger, K.S. Thygesen, I.E.L. Stephens, J. Rossmeisl, Fundamental limitation of electrocatalytic methane conversion to methanol, Physical Chemistry Chemical Physics 20(16) (2018) 11152-11159.

[51] R.S. Rocha, L.M. Camargo, M.R.V. Lanza, R. Bertazzoli, A Feasibility Study of the Electro-recycling of Greenhouse Gases: Design and Characterization of a (TiO2/RuO2)/PTFE Gas Diffusion Electrode for the Electrosynthesis of Methanol from Methane, Electrocatalysis 1(4) (2010) 224-229.

[52] R.L. Cook, A.F. Sammells, Ambient Temperature Methane Activation to Condensed Species under Cathodic Conditions, Journal of The Electrochemical Society 137(6) (1990) 2007-2008.

[53] L.M.S. Garcia, S. Rajak, K. Chair, C.M. Godoy, A.J. Silva, P.V.R. Gomes, E.A. Sanches, A.S. Ramos, R.F.B. De Souza, A. Duong, A.O. Neto, Conversion of Methane into Methanol Using the [6,6'-(2,2'-Bipyridine-6,6'-Diyl)bis(1,3,5-Triazine-2,4Diamine)](Nitrato-O)Coppe r(II) Complex in a Solid Electrolyte Reactor Fuel Cell Type, ACS Omega 5(26) (2020) 16003-16009.

[54] K.W. Frese, Partial electrochemical oxidation of methane under mild conditions, Langmuir 7(1) (1991) 13-15.

[55] M.E. O'Reilly, R.S. Kim, S. Oh, Y. Surendranath, Catalytic Methane Monofunctionalization by an Electrogenerated High-Valent Pd Intermediate, ACS Central Science 3(11) (2017) 1174-1179.

[56] M. Ahlquist, R.J. Nielsen, R.A. Periana, W.A. Goddard Iii, Product Protection, the Key to Developing High Performance Methane Selective Oxidation Catalysts, Journal of the American Chemical Society 131(47) (2009) 17110-17115.

[57] X. Cui, R. Huang, D. Deng, Catalytic conversion of C1 molecules under mild conditions, EnergyChem 3(1) (2021) 100050.

[58] M.C.L. Santos, L.C. Nunes, L.M.G. Silva, A.S. Ramos, F.C. Fonseca, R.F.B. de Souza, A.O. Neto, Direct Alkaline Anion Exchange Membrane Fuel Cell to Converting Methane into Methanol, ChemistrySelect 4(39) (2019) 11430-11434.

[59] K. Ogura, C.T. Migita, Y. Ito, Combined Photochemical and Electrochemical Oxidation of Methane, Journal of The Electrochemical Society 137(2) (1990) 500-503.

[60] L. Zeng, Z. Cheng, J.A. Fan, L.-S. Fan, J. Gong, Metal oxide redox chemistry for chemical looping processes, Nature Reviews Chemistry 2(11) (2018) 349-364.

[61] B.A. Jackson, E. Miliordos, Weak-field ligands enable inert early transition metal oxides to convert methane to methanol: the case of ZrO, Physical Chemistry Chemical Physics 22(12) (2020) 6606-6618.

[62] K.T. Dinh, M.M. Sullivan, K. Narsimhan, P. Serna, R.J. Meyer, M. Dincă, Y. Román-Leshkov, Continuous Partial Oxidation of Methane to Methanol Catalyzed by Diffusion-Paired Copper Dimers in Copper-Exchanged Zeolites, Journal of the American Chemical Society 141(29) (2019) 11641-11650.

[63] P. Velin, M. Ek, M. Skoglundh, A. Schaefer, A. Raj, D. Thompsett, G. Smedler, P.-A. Carlsson, Water Inhibition in Methane Oxidation over Alumina Supported Palladium Catalysts, The Journal of Physical Chemistry C 123(42) (2019) 25724-25737.

[64] X. Li, X. Wang, K. Roy, J.A. van Bokhoven, L. Artiglia, Role of Water on the Structure of Palladium for Complete Oxidation of Methane, ACS Catalysis 10(10) (2020) 5783-5792.

[65] C. Ma, X. Tan, H. Zhang, Q. Shen, N. Sun, W. Wei, Direct conversion of methane to methanol over Cu exchanged mordenite: Effect of counter ions, Chinese Chemical Letters 31(1) (2020) 235-238.

[66] N. Agarwal, S.J. Freakley, R.D. Armstrong, N. Dimitratos, Q. He, M. Douthwaite, D.J. Morgan, R.L. Jenkins, D.J. Willock, S.H. Taylor, C. Kiely, G. Hutchings, Low temperature selective oxidation of methane using unsupported gold-palladium colloidal catalysts, American Chemical Society, 2019, pp. COLL-0112.

[67] G.M. Tomboc, S. Choi, T. Kwon, Y.J. Hwang, K. Lee, Potential Link between Cu Surface and Selective CO2 Electroreduction: Perspective on Future Electrocatalyst Designs, Advanced Materials n/a(n/a) (2020) 1908398.

[68] J. Zheng, I. Lee, E. Khramenkova, M. Wang, B. Peng, O. Gutierrez, J.L. Fulton, D. Camaioni, R. Khare, A. Jentys, G. Haller, E. Pidko, M. Sanchez-Sanchez, J. Lercher, Importance of methane chemical potential for its conversion to methanol on Cuexchanged mordenite, Chemistry - A European Journal n/a(n/a) (2020).

[69] X. Zhang, A. Savara, R.B. Getman, A Method for Obtaining Liquid-Solid Adsorption Rates from Molecular Dynamics Simulations: Applied to Methanol on Pt(111) in H2O, Journal of Chemical Theory and Computation 16(4) (2020) $2680-2691$. 
[70] J. Baltrusaitis, D. Kiani, S. Sourav, I.E. Wachs, Single site vs crystalline: Promoted WO3/SiO2 catalyst design for oxidative coupling of methane (OCM), American Chemical Society, 2019, pp. CATL-0154.

[71] M.A. Hassan, T. Miyao, M. Komiyama, Catalytic oxidative coupling of methane in supercritical water: Investigations on a catalytically active species, The Journal of Supercritical Fluids 144 (2019) 8-13.

[72] P. Schwach, X. Pan, X. Bao, Direct Conversion of Methane to Value-Added Chemicals over Heterogeneous Catalysts: Challenges and Prospects, Chemical Reviews 117(13) (2017) 8497-8520.

[73] Y. He, C. Luan, Y. Fang, X. Feng, X. Peng, G. Yang, N. Tsubaki, Low-temperature direct conversion of methane to methanol over carbon materials supported Pd-Au nanoparticles, Catalysis Today 339 (2020) 48-53.

[74] C.G. Vayenas, S. Bebelis, C.J.C. Kyriazis, Cogeneration Electricity + Chemicals. 1. Solid Electrolytes, J Chemtech 21(7) (1991) 422428.

[75] L.W. Niedrach, Galvanostatic and Volumetric Studies of Hydrocarbons Adsorbed on Fuel Cell Anodes, Journal of The Electrochemical Society 111(12) (1964) 1309.

[76] L.W. Niedrach, S. Gilman, I. Weinstock, Studies of Hydrocarbon Fuel Cell Anodes by the Multipulse Potentiodynamic Method, Journal of The Electrochemical Society 112(12) (1965) 1161.

[77] L.W. Niedrach, M. Tochner, Studies of Hydrocarbon Fuel Cell Anodes by the Multipulse Potentiodynamic Method, Journal of The Electrochemical Society 114(1) (1967) 17.

[78] H. Binder, A. Köhling, H. Krupp, K. Richter, G. Sandstede, Electrochemical Oxidation of Certain Hydrocarbons and Carbon Monoxide in Dilute Sulfuric Acid, Journal of The Electrochemical Society 112(3) (1965) 355.

[79] T. Tagawa, K.K. Moe, M. Ito, S. Goto, Fuel cell type reactor for Chemicals-energy co-generation, Chemical Engineering Science 54(10) (1999) 1553-1557.

[80] S. Tyagi, A. Ganesh, P. Aghalayam, Direct Methane Proton Exchange Membrane Fuel Cell, ECS Transactions 6(25) (2019) 371378.

[81] J. Nandenha, I. Nagahama, J. Yamashita, E. Fontes, J. Ayoub, R. de Souza, F. Fonseca, A.O. Neto, Activation of methane on $\mathrm{PdZn} / \mathrm{C}$ electrocatalysts in an acidic electrolyte at low temperatures, International Journal of Electrochemical Science 14 (2019) 10819-10834.

[82] F. de Moura Souza, R.F.B. de Souza, B.L. Batista, M.C. dos Santos, F.C. Fonseca, A.O. Neto, J. Nandenha, Methane activation at low temperature in an acidic electrolyte using $\mathrm{PdAu} / \mathrm{C}, \mathrm{PdCu} / \mathrm{C}$, and $\mathrm{PdTiO} / \mathrm{C}$ electrocatalysts for PEMFC, Research on Chemical Intermediates 46(5) (2020) 2481-2496.

[83] K. Otsuka, I. Yamanaka, Electrochemical cells as reactors for selective oxygenation of hydrocarbons at low temperature, Catalysis Today 41(4) (1998) 311-325.

[84] A. Tomita, J. Nakajima, T. Hibino, Direct Oxidation of Methane to Methanol at Low Temperature and Pressure in an Electrochemical Fuel Cell, Angewandte Chemie International Edition 47(8) (2008) 1462-1464.

[85] N. Spinner, W.E. Mustain, Electrochemical Methane Activation and Conversion to Oxygenates at Room Temperature, Journal of The Electrochemical Society 160(11) (2013) F1275-F1281.

[86] J. Nandenha, R. Piasentin, L. Silva, E. Fontes, A. Neto, R. Souza, Partial oxidation of methane and generation of electricity using a PEMFC, Ionics 25(10) (2019) 5077-5082.

[87] M.C.L. Santos, C.M. Godoi, H.S. Kang, R.F.B. de Souza, A.S. Ramos, E. Antolini, A.O. Neto, Effect of Ni content in PdNi/C anode catalysts on power and methanol co-generation in alkaline direct methane fuel cell type, Journal of Colloid and Interface Science 578 (2020) 390-401.

[88] P.V. Nidheesh, M. Zhou, M.A. Oturan, An overview on the removal of synthetic dyes from water by electrochemical advanced oxidation processes, Chemosphere 197 (2018) 210-227.

[89] G. Nogami, Y. Nishiyama, H. Nakamura, New Approach to a Rotating Ring Disk Electrode, Journal of The Electrochemical Society 135(4) (1988) 877-884.

[90] C.M. Godoi, M.C.L. Santos, A.J. Silva, T.L. Tagomori, A.S. Ramos, R.F.B. de Souza, A.O. Neto, Methane conversion to higher value-added product and energy co-generation using anodes $\mathrm{OF} \mathrm{PdCu} / \mathrm{C}$ in a solid electrolyte reactor: alkaline fuel cell type monitored by differential mass spectroscopy, Research on Chemical Intermediates 47(2) (2021) 743-757.

[91] C.M. Godoi, M.C.L. Santos, A.J. Silva, T.L. Tagomori, A.S. Ramos, R.F.B. de Souza, A.O. Neto, Methane conversion to higher value-added product and energy co-generation using anodes $\mathrm{OF} \mathrm{PdCu} / \mathrm{C}$ in a solid electrolyte reactor: alkaline fuel cell type monitored by differential mass spectroscopy, Research on Chemical Intermediates 47(2) (2020) 743-757.

[92] N. Kiratzis, M. Stoukides, The Synthesis of Hydrogen Cyanide in a Solid Electrolyte Fuel Cell, Journal of The Electrochemical Society 134(8) (1987) 1925-1929.

[93] N.U. Pujare, A.F. Sammells, Methane Activation to C2 Hydrocarbon Species in Solid Oxide Fuel Cell, Journal of The Electrochemical Society 135(10) (1988) 2544-2545.

[94] K. Otsuka, K. Suga, I. Yamanaka, Oxidative coupling of methane applying a solid oxide fuel cell system, Catalysis Today 6(4) (1990) 587-592.

[95] X.-M. Guo, K. Hidajat, C.-B. Ching, An experimental study of oxidative coupling of methane in a solid oxide fuel cell with 1 wt\%Sr/La2O3-Bi2O3-Ag-YSZ membrane, Korean Journal of Chemical Engineering 15(5) (1998) 469-473.

[96] W. Kiatkittipong, S. Goto, T. Tagawa, S. Assabumrungrat, P. Praserthdam, Simulation of Oxidative Coupling of Methane in Solid Oxide Fuel Cell Type Reactor for C2 Hydrocarbon and Electricity Co-Generation, JOURNAL OF CHEMICAL ENGINEERING OF JAPAN 38(10) (2005) 841-848. 
[97] W. Wiyaratn, W. Appamana, S. Charojrochkul, S. Kaewkuekool, S. Assabumrungrat, Au/La1-xSrxMnO3 nanocomposite for chemical-energy cogeneration in solid oxide fuel cell reactor, Journal of Industrial and Engineering Chemistry 18(5) (2012) 18191823.

[98] T. Yamada, Y. Hiei, T. Akbay, T. Ishihara, Y. Takita, Simultaneous generation of synthesis gas and electric power by internal reforming fuel cells utilizing LaGaO3 based electrolytes, Solid State Ionics 113-115 (1998) 253-258.

[99] T. Ishihara, T. Yamada, T. Akbay, Y. Takita, Partial oxidation of methane over fuel cell type reactor for simultaneous generation of synthesis gas and electric power, Chemical Engineering Science 54(10) (1999) 1535-1540.

[100] V.A. Sobyanin, V.D. Belyaev, Gas-phase electrocatalysis: methane oxidation to syngas in a solid oxide fuel cell reactor, Solid State Ionics 136-137 (2000) 747-752.

[101] X. Zhang, S. Ohara, H. Chen, T. Fukui, Conversion of methane to syngas in a solid oxide fuel cell with Ni-SDC anode and LSGM electrolyte, Fuel 81(8) (2002) 989-996.

[102] Z. Zhan, Y. Lin, M. Pillai, I. Kim, S.A. Barnett, High-rate electrochemical partial oxidation of methane in solid oxide fuel cells, Journal of Power Sources 161(1) (2006) 460-465.

[103] M.R. Pillai, D.M. Bierschenk, S.A. Barnett, Electrochemical Partial Oxidation of Methane in Solid Oxide Fuel Cells: Effect of Anode Reforming Activity, Catalysis Letters 121(1) (2008) 19-23.

[104] F. Paloukis, S.G. Neophytides, Numerical simulation of methane fuelled cogenerative SOFCs for the production of synthesis gas and electrical energy, Chemical Engineering Science 62(15) (2007) 3868-3881.

[105] T. Brousas, P.H. Chiang, D. Eng, M. Stoukides, Technical and economic evaluation of a methane solid oxide fuel cell, Ionics 1(4) (1995) 328-337.

[106] B. Hua, N. Yan, M. Li, Y.-q. Zhang, Y.-f. Sun, J. Li, T. Etsell, P. Sarkar, K. Chuang, J.-L. Luo, Novel layered solid oxide fuel cells with multiple-twinned Ni0.8Co0.2 nanoparticles: the key to thermally independent $\mathrm{CO} 2$ utilization and power-chemical cogeneration, Energy \& Environmental Science 9(1) (2016) 207-215.

[107] B. Chen, H. Xu, Q. Sun, H. Zhang, P. Tan, W. Cai, W. He, M. Ni, Syngas/power cogeneration from proton conducting solid oxide fuel cells assisted by dry methane reforming: A thermal-electrochemical modelling study, Energy Conversion and Management 167 (2018) 37-44.

[108] B. Lee, Y. Sakamoto, D. Hirabayashi, K. Suzuki, T. Hibino, Direct oxidation of methane to methanol over proton conductor/metal mixed catalysts, Journal of Catalysis 271(2) (2010) 195-200.

[109] R. Serra-Maia, F.M. Michel, Y. Kang, E.A. Stach, Decomposition of Hydrogen Peroxide Catalyzed by AuPd Nanocatalysts during Methane Oxidation to Methanol, ACS Catalysis (2020) 5115-5123.

[110] P. Nematollahi, E.C. Neyts, Direct methane conversion to methanol on M and MN4 embedded graphene (M= Ni and Si): A comparative DFT study, Applied Surface Science 496 (2019) 143618.

[111] B. Wang, L. Tao, Y. Cheng, F. Yang, Y. Jin, C. Zhou, H. Yu, Y. Yang, Electrocatalytic Oxidation of Small Molecule Alcohols over $\mathrm{Pt}, \mathrm{Pd}$, and Au Catalysts: The Effect of Alcohol's Hydrogen Bond Donation Ability and Molecular Structure Properties, Catalysts 9(4) (2019).

[112] H.-B. Ma, T. Sheng, W.-S. Yu, J.-Y. Ye, L.-Y. Wan, N. Tian, S.-G. Sun, Z.-Y. Zhou, High Catalytic Activity of Pt(100) for CH4 Electrochemical Conversion, ACS Catalysis 9(11) (2019) 10159-10165.

[113] S. Hsieh, K. Chen, Anodic oxidation of methane, Journal of the Electrochemical Society 124(8) (1977) 1171.

[114] Z. Jin, L. Wang, E. Zuidema, K. Mondal, M. Zhang, J. Zhang, C. Wang, X. Meng, H. Yang, C. Mesters, F.-S. Xiao, Hydrophobic zeolite modification for in situ peroxide formation in methane oxidation to methanol, Science 367(6474) (2020) 193.

[115] Y. He, J. Liang, Y. Imai, K. Ueda, H. Li, X. guo, G. Yang, Y. Yoneyama, N. Tsubaki, Highly selective synthesis of methanol from methane over carbon materials supported Pd-Au nanoparticles under mild conditions, Catalysis Today 352 (2020) 104-110.

[116] R. McVicker, N. Agarwal, S.J. Freakley, Q. He, S. Althahban, S.H. Taylor, C.J. Kiely, G.J. Hutchings, Low temperature selective oxidation of methane using gold-palladium colloids, Catalysis Today 342 (2020) 32-38.

[117] W.G. Cortés Ortiz, D. Delgado, C.A. Guerrero Fajardo, S. Agouram, R. Sanchís, B. Solsona, J.M. López Nieto, Partial oxidation of methane and methanol on FeOx-, MoOx- and FeMoOx -SiO2 catalysts prepared by sol-gel method: A comparative study, Molecular Catalysis 491 (2020) 110982.

[118] K.T. Dinh, M.M. Sullivan, P. Serna, R.J. Meyer, M. Dincă, Y. Román-Leshkov, Viewpoint on the Partial Oxidation of Methane to Methanol Using Cu- and Fe-Exchanged Zeolites, ACS Catalysis 8(9) (2018) 8306-8313.

[119] H. Zuo, E. Klemm, Selective oxidation of methane with H2O2 over Fe-silicalite-1: An investigation of the influence of crystal sizes, calcination temperatures and acidities, Applied Catalysis A: General 583 (2019) 117121.

[120] Z. Liu, E. Huang, I. Orozco, W. Liao, R.M. Palomino, N. Rui, T. Duchoň, S. Nemšák, D.C. Grinter, M. Mahapatra, P. Liu, J.A. Rodriguez, S.D. Senanayake, Water-promoted interfacial pathways in methane oxidation to methanol on a CeO $<$ sub $>2</$ sub $>-$ $\mathrm{Cu}<\mathrm{sub}>2</$ sub $>$ O catalyst, Science 368(6490) (2020) 513-517.

[121] H. Furukawa, K.E. Cordova, M. O'Keeffe, O.M. Yaghi, The Chemistry and Applications of Metal-Organic Frameworks, Science 341(6149) (2013) 1230444.

[122] R. Babu, A.C. Kathalikkattil, R. Roshan, J. Tharun, D.-W. Kim, D.-W. Park, Dual-porous metal organic framework for room temperature CO2 fixation via cyclic carbonate synthesis, Green Chemistry 18(1) (2016) 232-242.

[123] P.G. Lustemberg, R.M. Palomino, R.A. Gutiérrez, D.C. Grinter, M. Vorokhta, Z. Liu, P.J. Ramírez, V. Matolín, M.V. GandugliaPirovano, S.D. Senanayake, J.A. Rodriguez, Direct Conversion of Methane to Methanol on Ni-Ceria Surfaces: Metal-Support Interactions and Water-Enabled Catalytic Conversion by Site Blocking, Journal of the American Chemical Society 140(24) (2018) $7681-7687$. 
[124] H. Sun, C. Liu, H. Chen, Nature of Cu active sites in zeolite-based catalysts for selective catalytic oxidation of methane, Res. Chem. Intermed. 45(12) (2019) 5849-5861.

[125] J. Kang, E.D. Park, Selective Oxidation of Methane over Fe-Zeolites by In Situ Generated H2o2., Catalyst 10(3) (2020) 299. 